\title{
The influence of typhoons on atmospheric composition deduced from IAGOS measurements over Taipei
}

\author{
Frank Roux ${ }^{1}$, Hannah Clark ${ }^{2}$, Kuo-Ying Wang ${ }^{3}$, Susanne Rohs $^{4}$, Bastien Sauvage ${ }^{1}$, and Philippe Nédélec ${ }^{1}$ \\ ${ }^{1}$ Laboratoire d'Aérologie, Université de Toulouse, Centre National de la \\ Recherche Scientifique, Toulouse, 31400, France \\ ${ }^{2}$ IAGOS-AISBL, 98 Rue du Trône, Brussels, 1050, Belgium \\ ${ }^{3}$ Department of Atmospheric Sciences, National Central University, Taoyuan City, 320, Taiwan \\ ${ }^{4}$ Forschungszentrum Jülich GmbH, Institut für Energie- und Klimaforschung Troposphäre (IEK-8), 52425 Jülich, Germany
}

Correspondence: Frank Roux (frank.roux@aero.obs-mip.fr)

Received: 1 July 2019 - Discussion started: 10 September 2019

Revised: 28 January 2020 - Accepted: 3 March 2020 - Published: 2 April 2020

\begin{abstract}
The research infrastructure IAGOS (In-Service Aircraft for a Global Observing System) equips commercial aircraft with instruments to monitor the composition of the atmosphere during flights around the world. In this article, we use data from two China Airlines aircraft based in Taipei (Taiwan) which provided daily measurements of ozone, carbon monoxide and water vapour throughout the summer of 2016. We present time series, from the surface to the upper troposphere, of ozone, carbon monoxide and relative humidity near Taipei, focusing on periods influenced by the passage of typhoons. We examine landing and takeoff profiles in the vicinity of tropical cyclones using ERA-5 reanalyses to elucidate the origin of the anomalies in the vertical distribution of these chemical species.

Results indicate a high ozone content in the upper- to middle-troposphere track of the storms. The high ozone mixing ratios are generally correlated with potential vorticity and anti-correlated with relative humidity, suggesting stratospheric origin. These results suggest that tropical cyclones participate in transporting air from the stratosphere to troposphere and that such transport could be a regular feature of typhoons. After the typhoons passed Taiwan, the tropospheric column was filled with substantially lower ozone mixing ratios due to the rapid uplift of marine boundary layer air. At the same time, the relative humidity increased, and carbon monoxide mixing ratios fell. Locally, therefore, the passage of typhoons has a positive effect on air quality at the surface, cleansing the atmosphere and reducing the mixing ratios of pollutants such as $\mathrm{CO}$ and $\mathrm{O}_{3}$.
\end{abstract}

\section{Introduction}

Tropospheric ozone $\left(\mathrm{O}_{3}\right)$ is an important trace gas from a climate and air-quality perspective. In the upper troposphere, small perturbations to the abundance of tropospheric ozone have relatively large radiative effects (Ramanathan et al., 1987; De Forster and Shine, 1997; Riese et al., 2012). Near the surface, ozone has harmful effects on human health and can significantly reduce agricultural yields (e.g. Yue and Unger, 2014). Tropospheric ozone is formed from the action of sunlight on precursors such as carbon monoxide (CO), nitrogen oxides $\left(\mathrm{NO}_{x}=\mathrm{NO}+\mathrm{NO}_{2}\right)$ and volatile organic compounds which are emitted through natural processes and by human activities. There is also a contribution to tropospheric ozone from stratosphere-to-troposphere transport (Holton et al., 1995) in synoptic events along the polar or subtropical jet stream such as tropopause folds and cut-off lows (Stohl et al., 2003; Gettelman et al., 2011) and related to deep convection associated with synoptic-scale circulations or mesoscale convective systems (Pan et al., 2014). Lightning activity is another source of ozone through the production of nitrogen oxides, which are efficient ozone precursors (Lelieveld and Crutzen, 1994). It is important to monitor the abundances and variability in tropospheric ozone and its precursors to better understand the budget of ozone in the troposphere, to understand impacts on surface air quality and because the long-range transport of air pollutants has effects on global atmospheric composition. 
The composition of the atmosphere is regularly monitored by IAGOS (In-Service Aircraft for a Global Observing System, a European Research Infrastructure; Petzold et al., 2015; Nédélec et al., 2015), where instruments carried on commercial airlines measure ozone, carbon monoxide and water vapor along with meteorological parameters and cloud particles. Ninety percent of the data are acquired in the upper troposphere-lower stratosphere (UTLS) when the aircraft attain cruising altitude somewhere between 300 and $180 \mathrm{hPa}(9$ to $12 \mathrm{~km}$ above mean sea level). At these altitudes, the correlations amongst the different trace gases can give insights into various mixing processes near the tropopause (e.g Hoor et al., 2002; Pan et al., 2004; Hegglin et al., 2009; Tilmes et al., 2010). Brioude et al. (2006) used IAGOS observations and Lagrangian analysis to confirm that a layer of enhanced ozone with low carbon monoxide and low relative humidity was due to a tropopause fold associated with a mid-latitude cyclone. More recently, a stratospheric intrusion associated with tropopause folds along the jet-stream axis of an upperlevel trough over Europe was captured by IAGOS observations (Akriditis et al., 2018). It led to increased ozone at the surface with negative consequences for air quality.

Tropical cyclones (TCs) - also named hurricanes in the Atlantic and the eastern North Pacific and typhoons in the western North Pacific - are deep convective synoptic-scale systems that can persist for several days. They are associated with significant vertical transport that can make significant perturbations to the structure and chemical composition of the UTLS. Moreover, strong convection in the eyewall region weakens the tropopause stability and facilitates stratosphere-troposphere exchange with possible ascent of humid and ozone-poor air from the lower troposphere and descent of dry and ozone-rich air from the lower stratosphere (Romps and Kuang, 2009; Zhan and Wang, 2012).

Several authors (Baray et al., 1999; Leclair de Bellevue et al., 2007; Das, 2009; Das et al., 2011, 2016; Jiang et al., 2015; Venkat Ratman et al., 2016) have emphasized the role of TCs in inducing stratosphere-to-troposphere exchange accompanied with increases in tropospheric ozone content. However, the structure and intensity of TCs vary with time, and observations of associated ozone perturbations have produced contrasting results. Penn (1965) reported increased values of ozone in the upper troposphere over the eye region of Hurricane Ginny (1963), but Penn (1966) showed no significant variation in ozone mixing ratio in the lower stratosphere down to the tropopause level above the Hurricane Isbell (1964) core. Newell et al. (1996) sampled the chemical structure of Typhoon Mireille (1991) during the Pacific Exploratory Mission - West A - campaign in 1991. They showed evidence of boundary layer air transported to the upper troposphere, but no evidence of ozone of stratospheric origin in the eye region. The numerical simulation of chemical transport associated with Mireille by Preston et al. (2019) confirmed that low-level polluted air with high concentration of $\mathrm{O}_{3}$ and $\mathrm{CO}$ was advected horizontally from large distances into the typhoon, transported up to the upper troposphere by eyewall convection and then detrained with the anticyclonic outflow away from the storm centre. Likewise, the reduced ozone content measured over and within the inner core region of TC Davina (1999) in the southwestern Indian ocean with the stratospheric research aircraft M55 Geophysica suggested a vigorous uplift of ozone-poor oceanic boundary layer air up to $16 \mathrm{~km}$ altitude, but no stratospheric intrusion of dry ozone-rich air was detected in the upper troposphere (Cairo et al., 2008). The EP/TOMS (Total Ozone Mapping Spectrometer onboard the Earth Probe Satellite) total ozone data for 11 North Atlantic hurricanes (1996-2003) and one western North Pacific typhoon (2001) analysed by Zou and $\mathrm{Wu}$ (2005) revealed that variations in total ozone column (TOC) are closely related to intensity changes of TCs. Intensified deep-convection-transported ozone-poor air from the oceanic boundary layer in the upper troposphere caused a decrease in TOC. Midya et al. (2012) showed that TCs over the Bay of Bengal and the Arabian Sea for the period 1997-2009 exhibited similar changes, with TOC decreasing steadily during the formation and intensification of a cyclone but increasing during its dissipation.

Lightning activity in tropical cyclones is another potential source of ozone through the associated production of nitrous oxides. Analysing ozone profiles downstream of Atlantic hurricanes, Jenkins et al. (2015) found increased ozone mixing ratios in the middle and upper troposphere they associated with outflows of lightning-induced $\mathrm{NO}_{x}$ from intense convective cells in the eyewall and the outer rainbands. Lightning outbreaks in tropical cyclones occur mostly during intensification phases (e.g. Xu et al., 2017), but some weakening storms can also be very active (e.g. DeMaria et al., 2012).

The western North Pacific has some of the most intense cyclonic activity worldwide. On average, six typhoons make landfall annually on the southern Chinese coast (Zhang et al., 2013), where they have been shown to have consequences for the abundance of surface and tropospheric ozone. Major pollution episodes in Hong Kong and the Pearl River Delta region in summer were related to the presence of tropical storms in the western North Pacific or the East and South China seas (Lee et al., 2002; Huang et al., 2005; Feng et al., 2007; Yang et al. 2012; Wei et al., 2016; Chow et al., 2018), when the low-level northwesterly to westerly winds induced by the storms prior to landfall transported ozone precursors from anthropogenic sources in the urbanized and industrialized Pearl River Delta in Guangdong province, China. Stable weather conditions with calm winds, low humidity, strong solar radiation and high temperatures that prevailed when typhoons were 500 to $1000 \mathrm{~km}$ offshore were a favourable environment for active photochemical reactions and contributed to the occurrence of the ozone episodes. Likewise, Hung and Lo (2015) showed that an increase in surface ozone concentration over southwestern Taiwan 2 to $4 \mathrm{~d}$ before the passage of typhoons was mainly due to leeward-side effects 
when the cyclonic easterly or northeasterly flow was partially blocked by the Central Mountain Range. The resulting atmospheric subsidence and stable weather conditions reduced vertical mixing and provided a favourable environment for ozone locally produced by photochemical reactions under strong solar radiation to accumulate in the lower troposphere over southwestern Taiwan.

Since 2012, China Airlines has been operating two IAGOS-equipped aircraft from its base in Taipei, Taiwan. Taiwan is situated in one of the most active paths for the TCs that form in the western North Pacific in the Northern Hemisphere and experiences three to four TCs per year (Chen et al., 2015). Here we use the IAGOS dataset over the period 1 July to 31 October 2016 to investigate the influence of typhoons passing near Taiwan on ozone content and tropospheric dynamics. Section 2 gives information on the data and the methods used to analyse them. Section 3 presents the statistics of ozone, carbon monoxide and relative humidity from the surface to the upper troposphere from July to October, deduced from IAGOS measurements made during take-off and landing at Taipei and from ERA-5 reanalyses. Section 4 discusses the vertical profiles of ozone and carbon monoxide from IAGOS data, in relation to potential vorticity (PV), relative humidity and vertical velocity fields from ERA-5 reanalyses. We show examples for three typhoons (typhoons Nepartak on 6-7 July 2016, Nida on 3031 July 2016 and Megi on 25-26 September 2016), where the IAGOS data allow us to identify a clear subsidence of ozone-rich air coming from the tropopause region. Section 5 puts these results into the context of similar observations over other basins. Section 6 gives the conclusion and some perspectives.

\section{Data and methods}

\subsection{IAGOS data}

Full details of the IAGOS system and its operation can be found in Petzold et al. (2015) and Nédélec et al. (2015). Ozone is measured using a dual-beam ultraviolet absorption monitor with a response time of $4 \mathrm{~s}$ and an accuracy estimated at about \pm 2 parts per billion by volume (ppbv; Thouret et al., 1998). Carbon monoxide is measured with an infrared analyser with a time resolution of $30 \mathrm{~s}(7.5 \mathrm{~km}$ at cruise speed of $900 \mathrm{~km} \mathrm{~h}^{-1}$ ) and a precision estimated at \pm 5 ppbv (Nédélec et al., 2003). Test flights showed the stability of the measurements at concentrations above $40 \mathrm{ppbv}$ and a minimum detectable concentration of $10 \mathrm{ppbv}$.

The water vapor mixing ratio is measured by the IAGOS Capacitive Hygrometer (Neis et al., 2015). IAGOS data provide values of relative humidity with respect to liquid water (RHL). The absolute uncertainty in RHL is estimated to be $\pm 5 \%$ with a response time of about $1 \mathrm{~min}$ at cruising altitude. The relative humidity (RH) values were recalculated here using the water vapor volume mixing ratio and air temperature and pressure to account for saturation with respect to liquid water at temperatures warmer than $0{ }^{\circ} \mathrm{C}$ and to ice at temperatures colder than $-20^{\circ} \mathrm{C}$, with linear interpolation between these two limits, using the Goff and Gratch (1946) equations, which are generally considered to be a reference (e.g. Gibbins, 1990).

China Airlines equipped their first aircraft in 2012, becoming the first Asian carrier to join IAGOS. Clark et al. (2015) described the composition of the UTLS over the northern Pacific using data collected at cruising altitude during the first 2 months of operation. A second China Airlines aircraft was equipped in July 2016, and a third was equipped in July 2017. During the summer of 2016, two aircraft made up to five flights a day from Taipei, offering transects in the UTLS and profiles at airports around the northwestern Pacific that were affected by typhoons in 2016 .

\subsection{ERA-5 reanalyses}

ERA-5 is the fifth generation of the European Centre for Medium-Range Weather Forecasts (ECMWF) atmospheric reanalyses of the global climate (Hersbach and Dee, 2016). It was produced using 4D-Var data assimilation in CY41r2 of ECMWF's Integrated Forecast System (IFS) coupled to a soil model and an ocean wave model. ERA-5 provides hourly estimates of a large number of atmospheric, land and oceanic climate variables. The data cover the Earth on a $30 \mathrm{~km}$ grid and resolve the atmosphere using 137 hybrid sigma and pressure levels from the surface up to a height of $80 \mathrm{~km}$. ERA5 reanalyses offer a more precise description of the atmosphere, with improved spatial resolution, better physics, and advanced modelling and data assimilation compared to the previous ERA-Interim reanalyses (Dee et al., 2011).

\subsection{The use of potential vorticity}

PV is defined as the scalar product of the absolute vorticity vector $\zeta_{\mathrm{a}}$ and the gradient of potential temperature $\theta$, divided by the air density $\rho$ :

$\mathrm{PV}=\frac{\zeta_{\mathrm{a}} \nabla \theta}{\rho}=\frac{1}{\rho}(2 \Omega+\nabla \times v) \nabla \theta$,

where $\Omega$ is the angular velocity vector of the Earth's rotation, $v$ is the three-dimensional velocity relative to the rotating Earth and $\nabla$ is the three-dimensional vector differential operator. PV is conventionally expressed in PV units (1 PVU $\left.=10^{-6} \mathrm{~K} \mathrm{~m}^{2} \mathrm{~kg}^{-1} \mathrm{~s}^{-1}\right)$. The PV tendency equation can be written as

$\frac{\partial \mathrm{PV}}{\partial t}+(v \nabla) \mathrm{PV}=\frac{1}{\rho}(\nabla \times F) \nabla \theta+\nabla \dot{\theta}$,

where $F$ is the friction or dissipation force and $\dot{\theta}$ is the diabatic heating rate.

The troposphere and the stratosphere have very different properties in terms of relative humidity, PV and chemical 
species like ozone. The air is moister in the troposphere than in the stratosphere, whereas PV values and ozone content are higher in the stratosphere. Since potential vorticity is conserved in adiabatic and frictionless flow, an intrusion of stratospheric air into the upper troposphere can be followed in space and time by considering anomalies of PV and RH. In tropical cyclones, the rate of latent heating peaks in the mid-troposphere, so the rate of PV creation is positive below this maximum and negative above it, leading to a vertically oriented dipole. As the heating-induced radialvertical circulation develops, the positive (cyclonic) PV values in the lower troposphere are carried aloft, while the negative (anticyclonic) ones in the upper troposphere are dragged by the upper-level outflow to larger radii. Therefore, a mature vortex is characterized by a positive PV anomaly extending through much of the troposphere, with negative values in a wider but shallower layer below the tropopause. In the upper-troposphere outflow layer, at large distances $(\geq 500 \mathrm{~km})$ from the cyclone core, where diabatic heating and friction are small, PV must be nearly conserved following air parcels and may be a good indicator of large-scale horizontal and vertical motions (e.g. Molinari et al., 1998 ; Leclair de Bellevue et al., 2007).

\section{Vertical profiles of tropospheric ozone, carbon monoxide and relative humidity at Taipei}

Figure 1 shows box fits of ozone, carbon monoxide and relative humidity between the surface and $12 \mathrm{~km}$ altitude, calculated from over 300 profiles collected by the two IAGOSequipped aircraft for 1 July to 31 October 2012-2016 during take-offs and landings at Taoyuan International Airport (International Air Transport Association code: TPE; $25.076^{\circ} \mathrm{N}$, $121.224^{\circ} \mathrm{E}$ ), located about $40 \mathrm{~km}$ west of Taipei. Relative humidity (Fig. 1a) is relatively high, especially below $5 \mathrm{~km}$ altitude. In Taiwan, July-October is the predominant wet period because of the summer monsoon, with the frequent occurrence of rain events carrying moist air aloft, interspersed with anticyclonic drier periods which account for sporadic low $\mathrm{RH}$ values above $5 \mathrm{~km}$ altitude. Ozone mixing ratios (Fig. 1b) in the lower troposphere are typically 30 to $50 \mathrm{ppbv}$, with sometimes larger values up to $140-150 \mathrm{ppbv}$ below $2 \mathrm{~km}$ altitude, probably related to episodes of high pollution. The mean ozone content is slightly larger above $7 \mathrm{~km}$ altitude, with the occasional occurrence of subsiding ozonerich stratospheric air when anticyclonic high pressures predominate over Taiwan. The mixing ratio of carbon monoxide (Fig. 1c) decreases almost linearly with altitude. Large values $(>500 \mathrm{ppbv})$ are sporadically observed below $4 \mathrm{~km}$ altitude during high-pollution events, whereas $\mathrm{CO}$ content rarely exceeds 200-250 ppbv above $8 \mathrm{~km}$.

More precisely, the evolution of the vertical profiles of relative humidity, ozone and carbon monoxide from 1 July to 31 October 2016 reveals distinct periods (Fig. 2). Before- hand, comparisons with vertical profiles of mean relative humidity (using the same Goff and Gratch, 1946, equations and temperature thresholds, potential vorticity, and vertical velocity derived from ERA-5 reanalyses within $300 \mathrm{~km}$ from TPE for the same period; Fig. 3) allow us to place the IAGOS measurements into their meteorological context. Although there are some differences between both $\mathrm{RH}$ values, the overall alternation of dry $(\mathrm{RH}<50 \%)$ and wet $(\mathrm{RH}>50 \%)$ episodes is remarkably similar.

Wet periods in Figs. 2a and 3a were associated with mean upward motion (Fig. 3c) and relatively low ( $<50$ ppbv) ozone content (Fig. 2b), corresponding to the upward transport of relatively clean air from the nearby oceanic boundary layer associated with the occurrence of convective systems. Among these events, seven tropical storms and typhoons that passed close to TPE are indicated with black lines in Figs. 2 and 3: Nepartak on 7 July at 00:00 UTC, Nida on 31 July at 12:00 UTC, Meranti on 13 September at 00:00 UTC, Malakas on 16 September at 12:00 UTC, Megi on 26 September at 00:00 UTC, Sarika on 16 October at 00:00 UTC and Haima on 19 October at 12:00 UTC. Four of them, Nepartak, Meranti, Malakas and Megi, were close enough to TPE to also be identified with positive PV values in the mid-troposphere to upper troposphere (Fig. 3b). Other moist periods on 18-20 July, 10-12 August, 5-10 September and 8-10 October were associated with more or less organized convective systems embedded in a larger-scale ensemble spanning the South and/or the East China seas.

Except for a wet episode on 10-12 August, the month of August was generally characterized by dry RH $(<50 \%)$, relatively large $\mathrm{O}_{3}(>50 \mathrm{ppbv})$ and $\mathrm{CO}(>100 \mathrm{ppbv})$ content above $3 \mathrm{~km}$ altitude over TPE (Fig. 2). ERA-5 data show that, during this period, mean vertical motions were predominantly downward (Fig. 3c) and that potential vorticity reached unusually high values (>1PVU; Fig. 3b) down to $6 \mathrm{~km}$ altitude on 9, 19 and 25 August. Himawari- 8 satellite images in the water vapor and mid-infrared (6-7.5 $\mu \mathrm{m}$ wavelengths) channels 8,9 and 10 (not shown) indicate that in August 2016 Taiwan was only marginally affected by perturbed weather as dry conditions prevailed over most of the East China Sea. It is therefore reasonable to consider that the relatively high ozone content in August 2016 originated from the stratosphere in mostly anticyclonic and subsiding conditions in the local upper troposphere. It is worth noting that the highest mixing ratios of ozone (up to 100 ppbv; Fig. 2b) and carbon monoxide (up to $350 \mathrm{ppbv}$; Fig. 2c) below $2 \mathrm{~km}$ in altitude were observed on 29-31 August, just before a moist and cloudy zone moved westward and occupied a large zone from northern Vietnam to Japan.

From Figs. 2 and 3, it is difficult to identify clearly the influence of typhoons passing close to TPE on the physical and chemical characteristics of the troposphere. From 6 July to 20 October, 56 pseudo-vertical profiles were collected by the IAGOS-equipped aircraft taking off or landing at less than $1200 \mathrm{~km}$ from the centres of the seven above- 

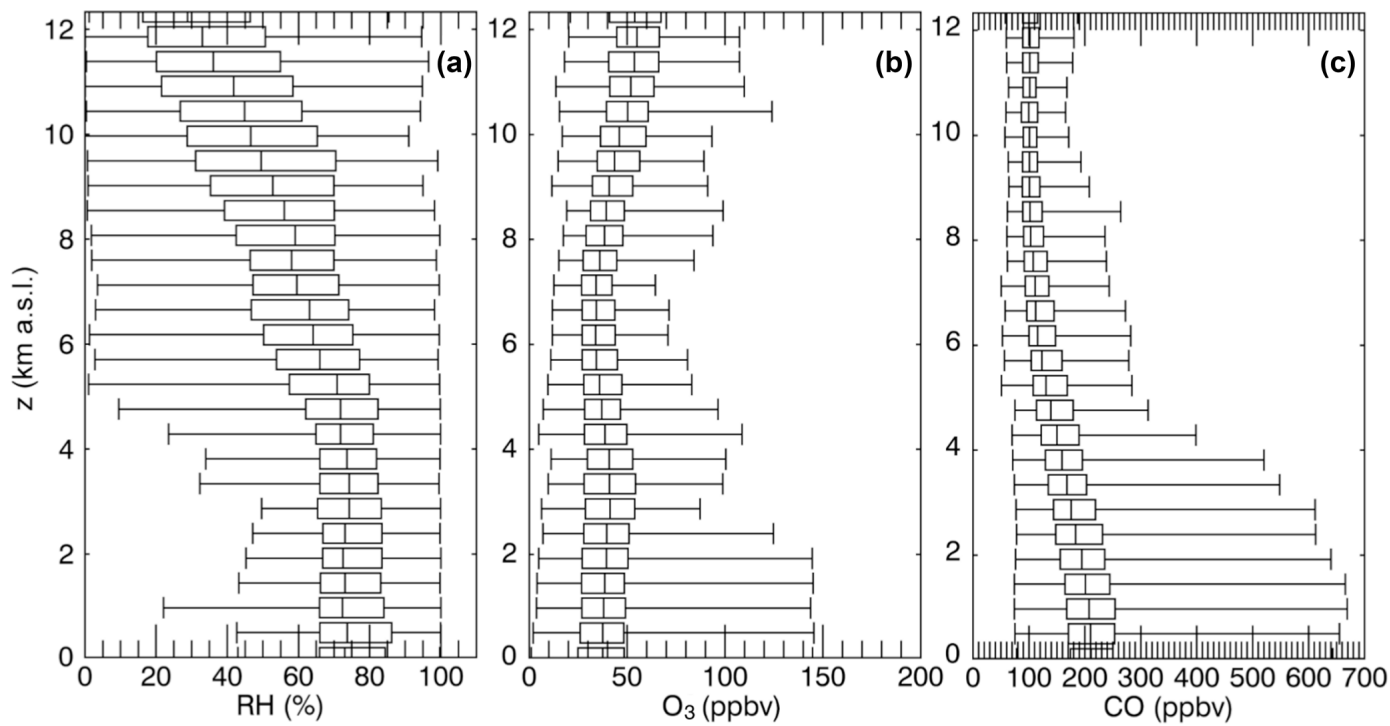

Figure 1. Boxplots showing first percentile, first quartile, median, third quartile and 99th percentile of (a) relative humidity (RH; limited to $100 \%$ ), (b) ozone $\left(\mathrm{O}_{3}\right)$ and (c) carbon monoxide $(\mathrm{CO})$ between 0 and $12 \mathrm{~km}$ altitude from IAGOS measurements during take-off from and landing to TPE over the time periods 1 July to 31 October in 2012-2016.

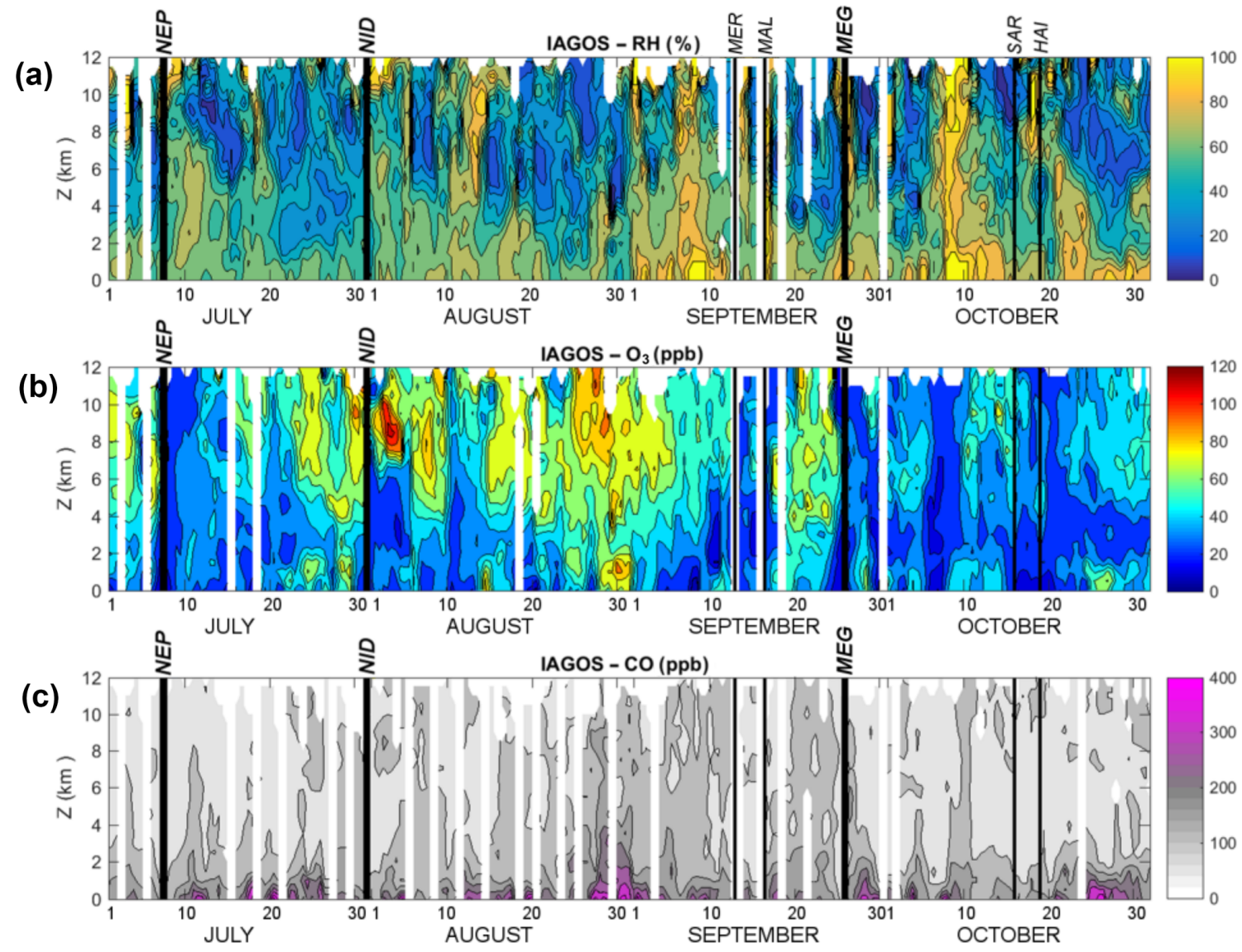

Figure 2. Vertical profiles derived from IAGOS measurements during take-off from and landing to TPE (Taoyuan International Airport; $25.076^{\circ} \mathrm{N}, 121.224^{\circ} \mathrm{E}$ ) from 1 July to 31 October 2016 for (a) relative humidity (in \%), (b) ozone mixing ratio (in parts per billion by volume - ppbv) and (c) carbon monoxide (in ppbv). Vertical black lines labelled NEP, NID, MER, MAL, MEG, SAR and HAI represent the closest approaches of typhoons Nepartak, Nida, Meranti, Malakas, Megi, Sarika and Haima, respectively. 


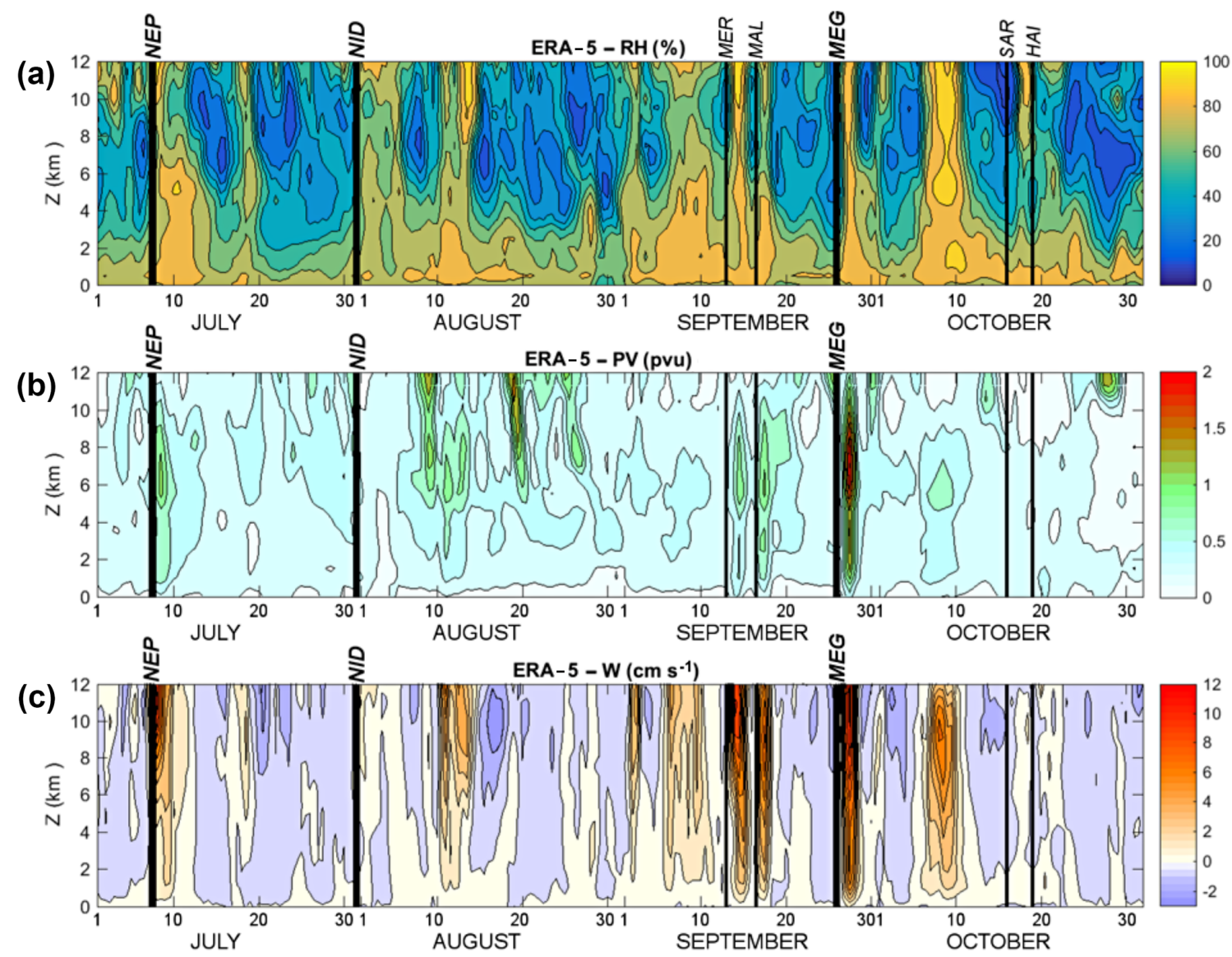

Figure 3. As in Fig. 2, except for vertical profiles derived from ERA-5 reanalyses within $300 \mathrm{~km}$ of TPE from 1 July to 31 October 2016 for (a) mean relative humidity (in \%), (b) mean potential vorticity (in potential vorticity units; $1 \mathrm{PVU}=10^{-6} \mathrm{~m}^{2} \mathrm{~s}^{-1} \mathrm{~K} \mathrm{~kg}^{-1}$ ) and (c) mean vertical velocity (in $\mathrm{cm} \mathrm{s}^{-1}$ ).

mentioned storms. Figure 4 shows the statistical distribution of relative humidity and ozone content derived from these data between 4 and $12 \mathrm{~km}$ altitude. Two populations can be identified: ozone-rich (50 to $100 \mathrm{ppbv})$ and dry $(\mathrm{RH}<50 \%)$ air represents $35.8 \%$ of the measurements, and ozone-poor ( $<50$ ppbv) air with various $\mathrm{RH}$ values $(20 \%$ to $100 \%)$ accounts for the remaining $64.2 \%$. The absence of measurements with positive ozone anomaly and high relative humidity indicates that lightning-induced nitrogen oxides are probably not the main cause of ozone production here. These results bear some resemblance to those Randel et al. (2016) derived from vertical tropospheric profiles collected during the "Convective Transport and Active Species in the Tropics" experiment from Guam $\left(14^{\circ} \mathrm{N}, 145^{\circ} \mathrm{E}\right)$ in JanuaryFebruary 2014. They also observed dry air $(\mathrm{RH}<20 \%)$ with enhanced ozone (40-80 ppbv) contents within layers between 3 and $9 \mathrm{~km}$ altitudes, which they linked to quasiisentropic transport from the extratropical UTLS. These data were obtained in the descending branch of the Hadley cell, with only occasional deep convection, which contrasts with the moister and stormier conditions that prevailed during July to October 2016 near Taiwan. The following section shows more detailed analyses of the IAGOS and ERA-5 data for three typhoons in 2016.

\section{Physical and chemical impact of three typhoons}

The 2016 typhoon season in the western North Pacific was an average one, with a total of 26 named storms and 13 typhoons (RSMC Tokyo, 2017; JTWC Guam, 2017). Seven of them (Typhoon Nepartak on 6-7 July, Severe Tropical Storm Nida on 30-31 July, Typhoon Meranti on 11-13 September, Typhoon Malakas on 16 September, Typhoon Megi on 2526 September, Typhoon Sarika on 15-16 October and Typhoon Haima on 19-20 October) came close enough to Taiwan for vertical profiles of ozone, carbon monoxide and relative humidity to be obtained at less than $1000 \mathrm{~km}$ from their centre by IAGOS aircraft taking off or landing at TPE. The most favourable typhoon trajectories and detailed observations occurred for typhoons Nepartak, Nida and Megi (thick black lines in Figs. 2 and 3). In order to put the IAGOS observations from these three storms into a meteorological 


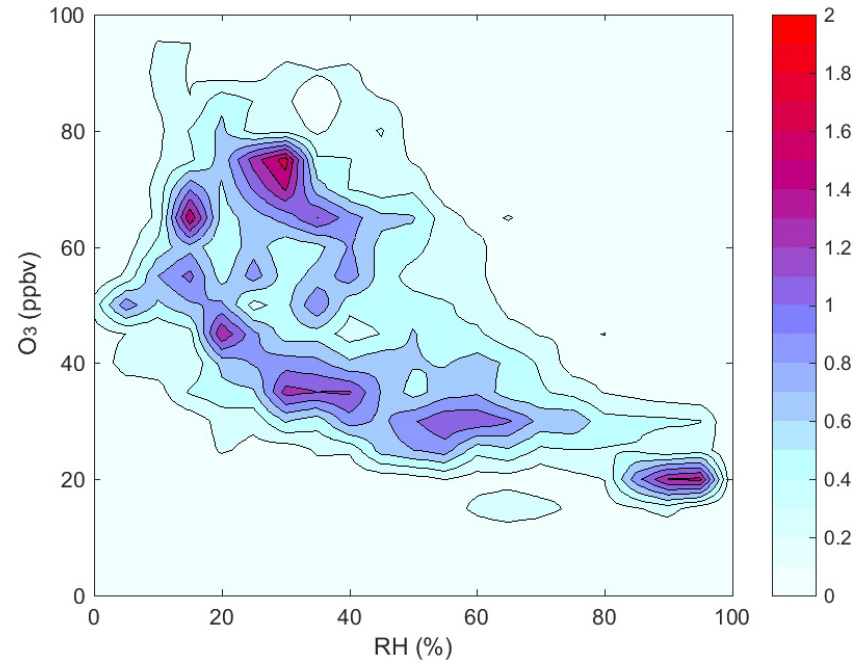

Figure 4. Two-dimensional distribution of ozone (in ppbv; 20 classes between 0 and $100 \mathrm{ppbv}$ ) and relative humidity (in \%; 20 classes between $0 \%$ and $100 \%$ ) from 4 to $12 \mathrm{~km}$ altitudes for 56 vertical profiles derived from IAGOS measurements during take-off from and landing to TPE at less than $1200 \mathrm{~km}$ from the centres of tropical storms and typhoons Nepartak, Nida, Meranti, Megi, Sarika and Haima during July to October 2016.

context, and to detail the influence of typhoons on the physical and chemical characteristics of the local troposphere, we combine the IAGOS observations with images from the Japanese Himawari-8 geostationary satellite and meteorological fields from ERA-5 reanalyses. The relatively fine resolution $(\approx 25 \mathrm{~km}$ horizontally) of ERA-5 reanalyses provides detailed information that was not available in previous studies.

\subsection{Typhoon Nepartak on 6-7 July 2016}

Starting as a low-pressure area south of Guam $\left(13.50^{\circ} \mathrm{N}\right.$, $144.80^{\circ} \mathrm{E}$ ) on $30 \mathrm{June}$, then becoming a tropical depression on 2 July and a tropical storm on 3 July, Nepartak became a typhoon on 4 July. It reached its peak intensity on 6 July at 12:00 UTC as a Category 5 equivalent supertyphoon with a central pressure at $900 \mathrm{hPa}$ and $10 \mathrm{~min}$ averaged maximum winds at $205 \mathrm{~km} \mathrm{~h}^{-1}\left(\approx 55 \mathrm{~m} \mathrm{~s}^{-1}\right.$; Fig. 5a). At that time, its centre was located about $700 \mathrm{~km}$ to the southeast of Taiwan. Nepartak started to weaken on 7 July in the afternoon, when its circulation began to interact with the topography of Taiwan. It crossed Taiwan, then emerging into the Taiwan Strait as a weaker Category 1 typhoon on 8 July. Nepartak made final landfall $1 \mathrm{~d}$ later in China's Fujian province.

Relevant IAGOS observations were collected during six selected take-offs and landings at TPE from 6 July at 04:57 UTC to 7 July at 11:18 UTC, numbered from NEP-1 to NEP-6 (in Fig. 6). To put these quasi-vertical profiles into the meteorological environment of Typhoon Nepartak, we positioned them in a reference frame moving with the storm at
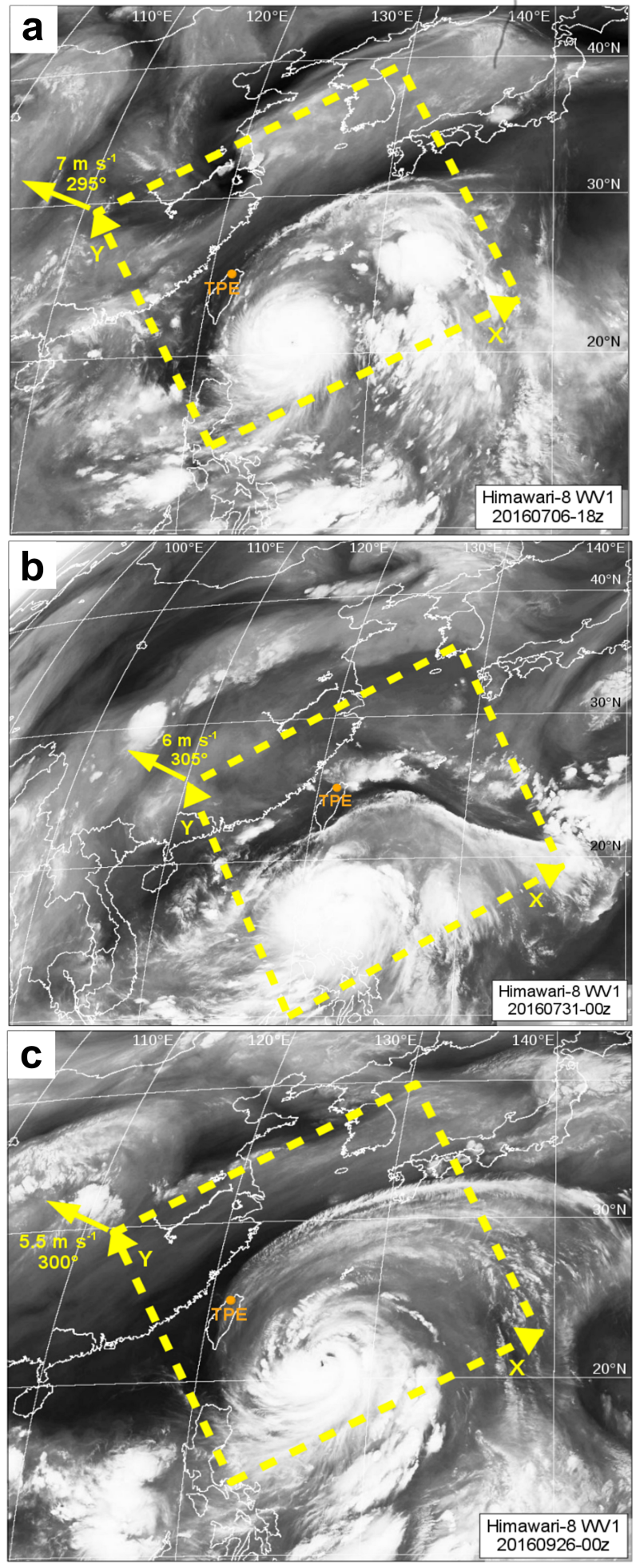

Figure 5. Himawari-8 Channel $8(6.06-6.43 \mu \mathrm{m})$ "Water Vapor" images on (a) 6 July 2016 at 18:00 UTC for Typhoon Nepartak, (b) 31 July 2016 at 00:00 UTC for Severe Tropical Storm Nida and (c) 26 September 2016 at 00:00 UTC for Typhoon Megi. Orange dot labelled TPE indicates the location of the Taiwan Taoyuan International airport. The yellow boxes denote the $2000 \mathrm{~km} \times 2000 \mathrm{~km}$ region where ERA-5 reanalyses data were composited ( $x$ and $y$ axes and storm motion are indicated) for each storm. 

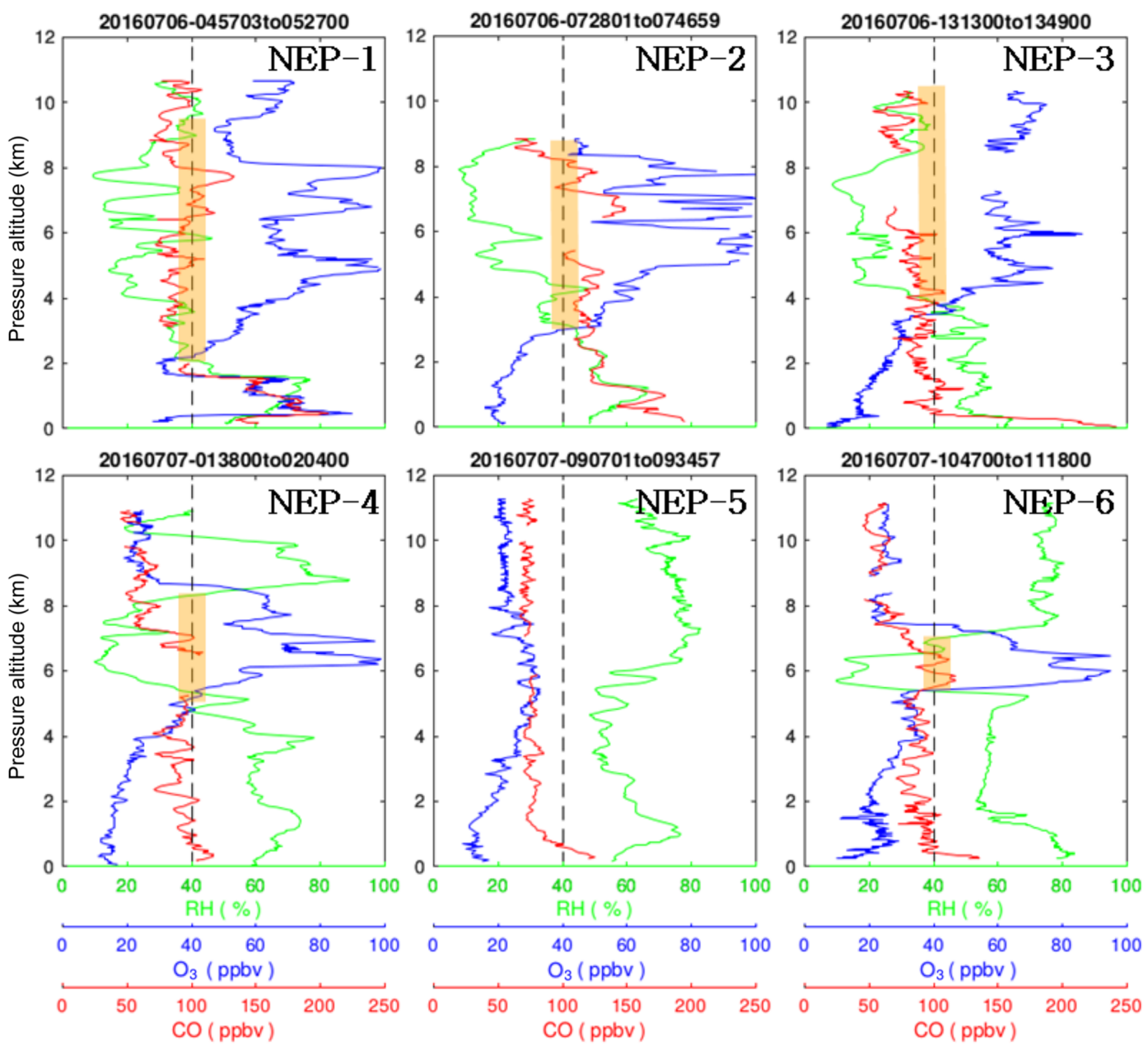

Figure 6. Vertical profiles of relative humidity RH (green curves; in \%), ozone $\mathrm{O}_{3}$ (blue curves; in parts per billion by volume - ppbv) and carbon monoxide CO (red curves; in ppbv) from the six take-offs from and landings to TPE of IAGOS aircraft on 6-7 July shown in Fig. 5. The dashed line is an arbitrary limit separating dry $(\mathrm{RH}<40 \%)$ and moist $(\mathrm{RH}>40 \%), \mathrm{O}_{3}$-poor $(<40 \mathrm{ppbv})$ and $\mathrm{O}_{3}$-rich $(>40 \mathrm{ppbv})$, and CO-poor $(<100 \mathrm{ppbv})$ and CO-rich $(>100 \mathrm{ppbv})$ air masses. Thick orange segments indicate regions with dry and $\mathrm{O}_{3}$-rich air.

$7 \mathrm{~m} \mathrm{~s}^{-1}$ from $295^{\circ}$ with its origin at $12.18^{\circ} \mathrm{N}, 125.10^{\circ} \mathrm{E}$, on 6 July at 00:00 UTC. In this reference frame, profile NEP-1 is the furthest from the centre of Nepartak and NEP-6 is the closest, as the airport gets closer with time to the centre of the typhoon. Figure 7 shows the result from the combination of seven 6-hourly ERA-5 reanalyses from 6 July at 00:00 UTC to 7 July at 12:00 UTC in this reference frame moving with Nepartak. The white dotted line, referred to as the " $S$ axis" in Fig. 7a, represents the pseudo-path of TPE airport with respect to Nepartak (rather than the storm track of Nepartak relative to the airport). Figure 7a shows the horizontal distribution of relative integrated humidity (RIH), deduced from actual and saturated mixing ratios over altitudes between 4 and $10 \mathrm{~km}$. We can see the moist central and eastern parts of Nepartak with $\mathrm{RIH} \geq 80 \%$ and a large region of dry air with RIH $\leq 40 \%$ to the northwest. There is a very good correlation between moist and dry zones from ERA-5 (Fig. 7a) and the bright and dark regions from Himawari- 8 Channel 8
(6.06-6.43 $\mu \mathrm{m})$ "Water Vapor" images (Fig. 5a). The mean potential vorticity (MPV) field between 8 and $12 \mathrm{~km}$ altitude (Fig. 7b) reveals large positive values ( $>2$ PVU) in the upper core region of Nepartak and a south-north-oriented band of weaker positive values ( $>0.5 \mathrm{PVU})$ at the eastern limit of the dry zone. This region was associated with mean downward motion at altitudes between 6 and $10 \mathrm{~km}$, shown by the black line in Fig. 7b. The descent rate was greater than $-1 \mathrm{~cm} \mathrm{~s}^{-1}$, which is significantly larger than the typical value for tropical clear-sky regions (Gettelman et al., 2004; Das et al., 2016).

In Fig. 7c and d, we present cross sections of the relative humidity and PV averaged over $\pm 500 \mathrm{~km}$ on either side of the pseudo-path of TPE in the frame moving with the typhoon ( $S$ axis in Fig. 6a). Comparison of Fig. 7c and $\mathrm{d}$ reveals that the dry zone was related to a region of air with MPV values larger than 1 PVU, originating from the tropopause region near $15 \mathrm{~km}$ altitude. Though such values are less than the $2 \mathrm{PVU}$ threshold commonly used to 


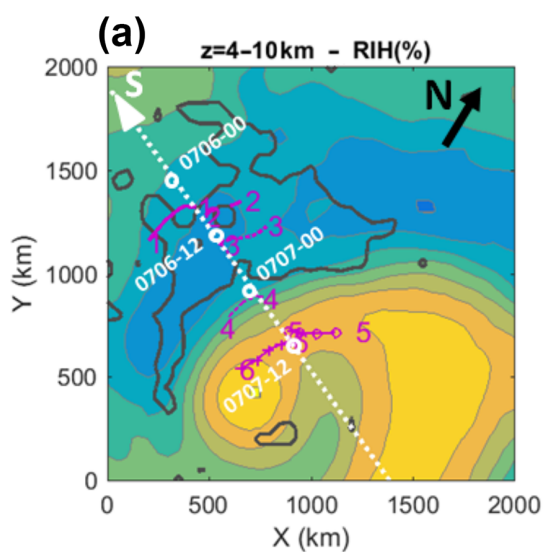

(c) OBLQUE CROSS SECTION - RHH\%)
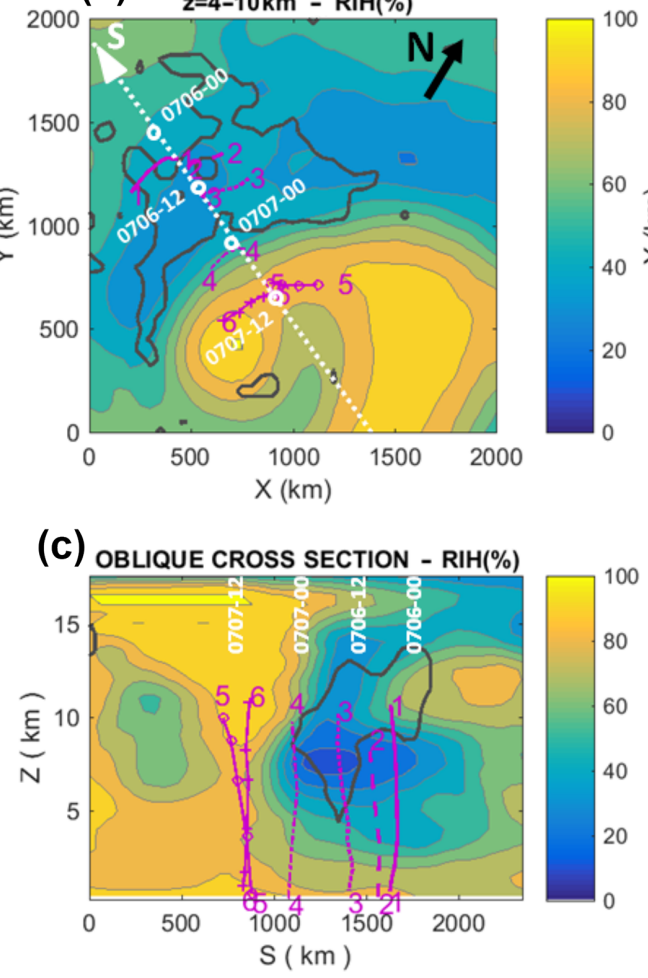

(b)

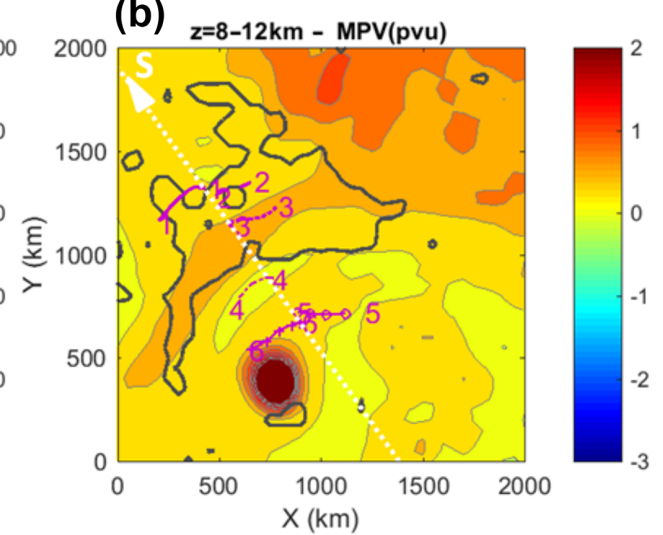

(d) OBLIQUE CROSS SECTION - MPV(pvu)

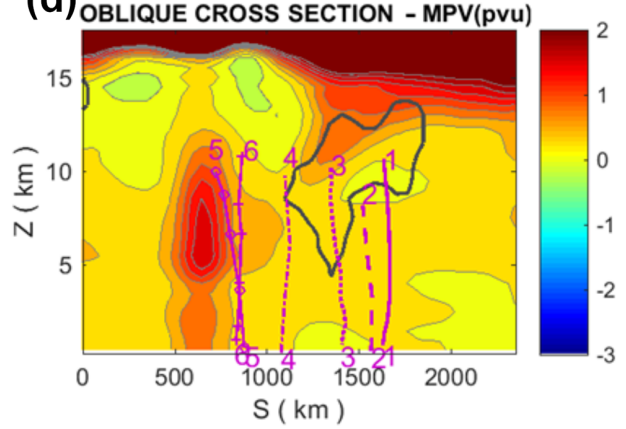

Figure 7. Composites of ERA-5 reanalyses data from 6 July at 00:00 UTC to 7 July at 12:00 UTC in the domain shown in Fig. 5a. Above are horizontal distributions of (a) relative integrated humidity (RIH) between 4 and $10 \mathrm{~km}$ altitude (in \%) and (b) mean potential vorticity (MPV) between 8 and $12 \mathrm{~km}$ altitude (in PVU; $=10^{-6} \mathrm{~m}^{2} \mathrm{~s}^{-1} \mathrm{~K} \mathrm{~kg}^{-1}$ ). North is indicated in (a). The dotted white line ( $S$ axis) represents the pseudo-trajectory of TPE airport in the frame moving with Typhoon Nepartak (successive times are indicated). Below are vertical cross sections of (c) RIH (in \%), and (d) MPV (in PVU), averaged across $\pm 500 \mathrm{~km}$ along this oblique $S$ line. The solid black contours encompass mean downward velocities $<-1 \mathrm{~cm} \mathrm{~s}^{-1}$ between 6 and $10 \mathrm{~km}$ altitude. The purple lines 1 to 6 indicate the tracks of IAGOS aircraft during selected take-offs and landings on 6-7 July.

characterize stratospheric air, they are significantly higher than those observed in the troposphere, except in the vicinity of strong cyclonic perturbations such as typhoons. These high MPV values in the upper troposphere were also associated with downward motion $\left(<-1 \mathrm{~cm} \mathrm{~s}^{-1}\right)$ and dry air $(\mathrm{RIH}<40 \%$ ) down to $3 \mathrm{~km}$ altitude (Fig. $7 \mathrm{c}$ ). This feature is distinct from the high MPV and moist-RIH (>60\%) values associated with the core region of Typhoon Nepartak. Above $10 \mathrm{~km}$, negative MPV values with nearly saturated RIH below the tropopause, at $15 \mathrm{~km}$ altitude, resulted from the divergent and anticyclonic moist outflow from Nepartak. It should be noted that the dry-RIH and high-MPV zone seen in Figs. 5a and 7a and b was not stationary over the Taiwan Strait and mainland China, but rather it moved with Nepartak on 6-7 July, staying 500 to $1500 \mathrm{~km}$ to the northwest with limited deformation. Operational radiosoundings launched from World Meteorological Organization (WMO) station 58968 in Taipei $\left(25.0376{ }^{\circ} \mathrm{N}, 121.5150^{\circ} \mathrm{E}\right)$, about $30 \mathrm{~km}$ east of TPE, reveal that the altitude of the cold-point tropopause decreased from $18.2 \mathrm{~km}$ on 5 July at 00:00 UTC to $16.2 \mathrm{~km}$ on 6 July at 00:00 UTC, when the dry zone arrived over Taiwan (see Fig. 6). Such lowering of the tropopause (cold point) height was observed by Venkat Ratman et al. (2016) within $500 \mathrm{~km}$ of the centre of northern Indian Ocean cyclones.

From the correlations amongst the different chemical species measured by IAGOS, we can identify different air masses which are present at different altitudes within the successive profiles. In the UTLS over the North Pacific, IAGOS aircraft observed air masses with high humidity, medium concentration of $\mathrm{CO}(<100 \mathrm{ppbv})$ and low ozone content (20-40 ppbv), indicative of air from the marine boundary layer probably lifted aloft by deep convection (Clark et al., 2015). We focus here on identifying the chemical characteristics of the dry layers, which are influenced by subsiding motion a few hundred kilometres ahead of typhoon.

The first four vertical profiles derived from IAGOS measurements (NEP-1 to NEP-4 in Fig. 6) reveal that the dry layer above $5 \mathrm{~km}$ altitude was associated with a large ozone content, up to $100 \mathrm{ppbv}$. The mixing ratios of carbon monoxide seen at these altitudes were significantly lower than the values of 200 to $250 \mathrm{ppbv}$ observed near the surface. As dis- 


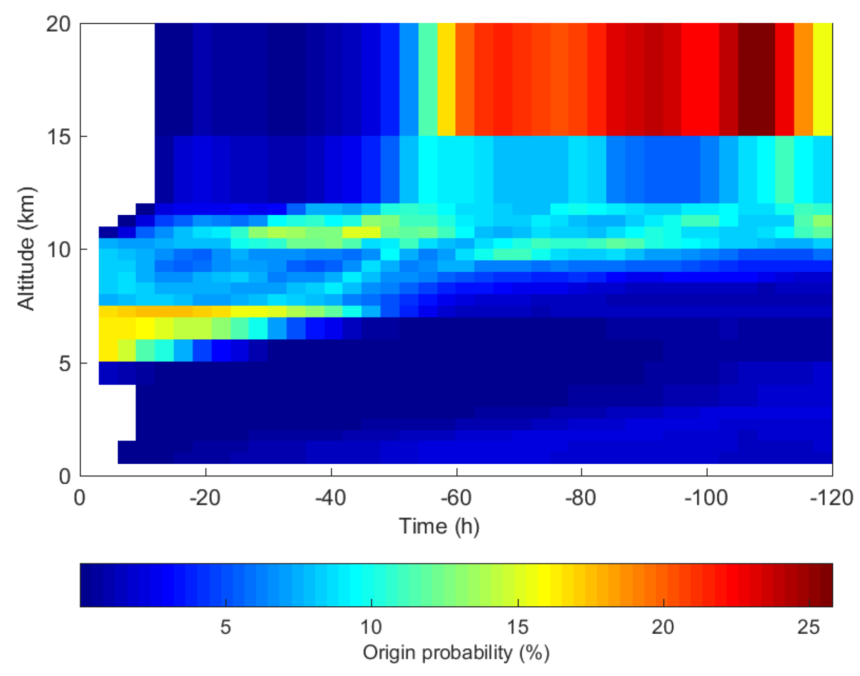

Figure 8. Time-altitude distribution of probability (in \%) of backtrajectory origin when initiated within the domain $24-26^{\circ} \mathrm{N}, 120$ $122^{\circ} \mathrm{E}$ (4-10 km altitude), on 6 July at 12:00 UTC.

cussed in Sect. 3, the dry and ozone-rich zone aloft probably did not result from the upward transport of polluted boundary layer air, and the ozone was not likely to be the result of lightning activity, as this would be a high-ozone and moistair combination (Jenkins et al., 2015). These four profiles lie within the region of subsiding motion as shown by the black contour on Fig. 7c and d, and in addition, they intercept the tongue of higher-PV air originating from the region above $15 \mathrm{~km}$ (Fig. 7d), suggesting that the high ozone is a result of stratosphere-to-troposphere inflow ahead of the approaching typhoon. The FLEXPART Lagrangian dispersion model (v9.0; Stohl et al., 2005) is used in order to determine the origin of $\mathrm{O}_{3}$-rich air masses. FLEXPART simulates transport, dispersion and turbulent mixing of tracer released from volume sources. Backward plumes of multiple (1 million) particles were initiated on 6 July at 12:00 UTC in the domain $4-26^{\circ} \mathrm{N}, 120-122^{\circ} \mathrm{E}$ (4-10 km altitude), encompassing the dry zone when it passed over TPE. Figure 8 shows that the probability that this dry and ozone-rich layer originated from the stratosphere above $15 \mathrm{~km}$ altitude exceeds $20 \%$ between 60 and $120 \mathrm{~h}$ before it arrived over TPE and was sampled by IAGOS aircraft.

Figure $7 \mathrm{c}$ and $\mathrm{d}$ show that profiles NEP-5 and NEP-6 were obtained in the more humid region close to Nepartak, except for the southern tip of the dry and ozone-rich ozone layer intercepted by profile NEP- 6 at $6 \mathrm{~km}$ altitude, which may be the remnants of a previous mixing or intrusion event. At altitudes above $6 \mathrm{~km}$, these profiles differ from the first four, as the ozone mixing ratio dropped by $70 \mathrm{ppbv}$ to around $20 \mathrm{ppbv}$, and the relative humidity increased from $10 \%$ to $80 \%$. The abundance of carbon monoxide is also slightly lower than in previous profiles. This humid and ozone-poor layer resulted probably from upward transport of clean humid air from the oceanic boundary layer by the typhoon. At altitudes below $2 \mathrm{~km}$, profiles NEP-4, NEP-5 and NEP-6, which are much closer to the typhoon, reveal that, when the centre of Nepartak was less than $500 \mathrm{~km}$ from Taipei, the characteristics in the lower atmosphere below $2 \mathrm{~km}$ altitude changed dramatically, with a strong decrease in $\mathrm{CO}$ and increase in relative humidity consistent with inflow of the cleaner and moist oceanic boundary layer air feeding the typhoon at the lower levels.

Below we present a further two typhoons in order to investigate how common these features are.

\subsection{Severe Tropical Storm Nida on 30-31 July 2016}

Formed as a tropical depression over the Philippine Sea during the night of 29-30 July, Nida followed a northwesterly track and intensified in the afternoon of 30 July. After developing into a severe tropical storm the next morning, it passed close to the north of Luzon (Philippines) on 31 July (Fig. 5b). When it entered the South China Sea, Nida further intensified into a severe tropical storm and reached its peak intensity on 31 July at 09:00 UTC, with maximum $10 \mathrm{~min}$ averaged winds at $110 \mathrm{~km} \mathrm{~h}^{-1}\left(\approx 30 \mathrm{~m} \mathrm{~s}^{-1}\right)$ and minimum central pressure at $975 \mathrm{hPa}$. At that time, the storm centre was about $400 \mathrm{~km}$ to the south-southeast of Taiwan. Nida made landfall near Dapeng Peninsula, east of Hong Kong, on the evening of 1 August, before weakening as it moved further inland and dissipating on 2 August.

IAGOS observations were obtained during six flights from TPE from 30 July at 09:55 UTC to 31 July at 21:40 UTC (Fig. 9). As in Fig. 7 above for Typhoon Nepartak, the profiles for Nida were put into their meteorological context derived from the combination of 6-hourly ERA-5 reanalyses from 30 July at 06:00 UTC to 1 August at 00:00 UTC in the reference frame moving with Nida, at $6 \mathrm{~m} \mathrm{~s}^{-1}$ towards $305^{\circ}$, with its origin at $7.4^{\circ} \mathrm{N}, 123^{\circ} 8 \mathrm{E}$, on 30 July at 00:00 UTC. The white dashed line (referred to as $S$ axis) in Fig. 10a again shows the pseudo-track of TPE airport in the reference frame of Nida. A comparison between Figs. 7a and 10a reveals that Nida passed at a larger distance from TPE than Nepartak. The relative integrated humidity between 4 and $10 \mathrm{~km}$ altitude (Fig. 10a) shows the moist central and eastern parts of Nida with RIH $\geq 80 \%$ and, as with Nepartak, a large region of dry air (RIH $\leq 40 \%)$ to the northwest. The mean potential vorticity between 8 and $12 \mathrm{~km}$ altitude (Fig. 10b) also reveals relatively large positive values $(>1 \mathrm{PVU})$ in the upper core region of Nida and a wide band with weaker positive values $(>0.5 \mathrm{PVU})$ in the dry region to the northwest. Mean downward motions between 6 and $10 \mathrm{~km}$ stronger than $-1 \mathrm{~cm} \mathrm{~s}^{-1}$ are also observed in this dry zone. For Typhoon Nida, the altitude of the cold-point tropopause deduced from the 12hourly Taipei radiosounding data (not shown) was between 16.6 and $17 \mathrm{~km}$ altitude, but it did not change significantly during the considered period. 

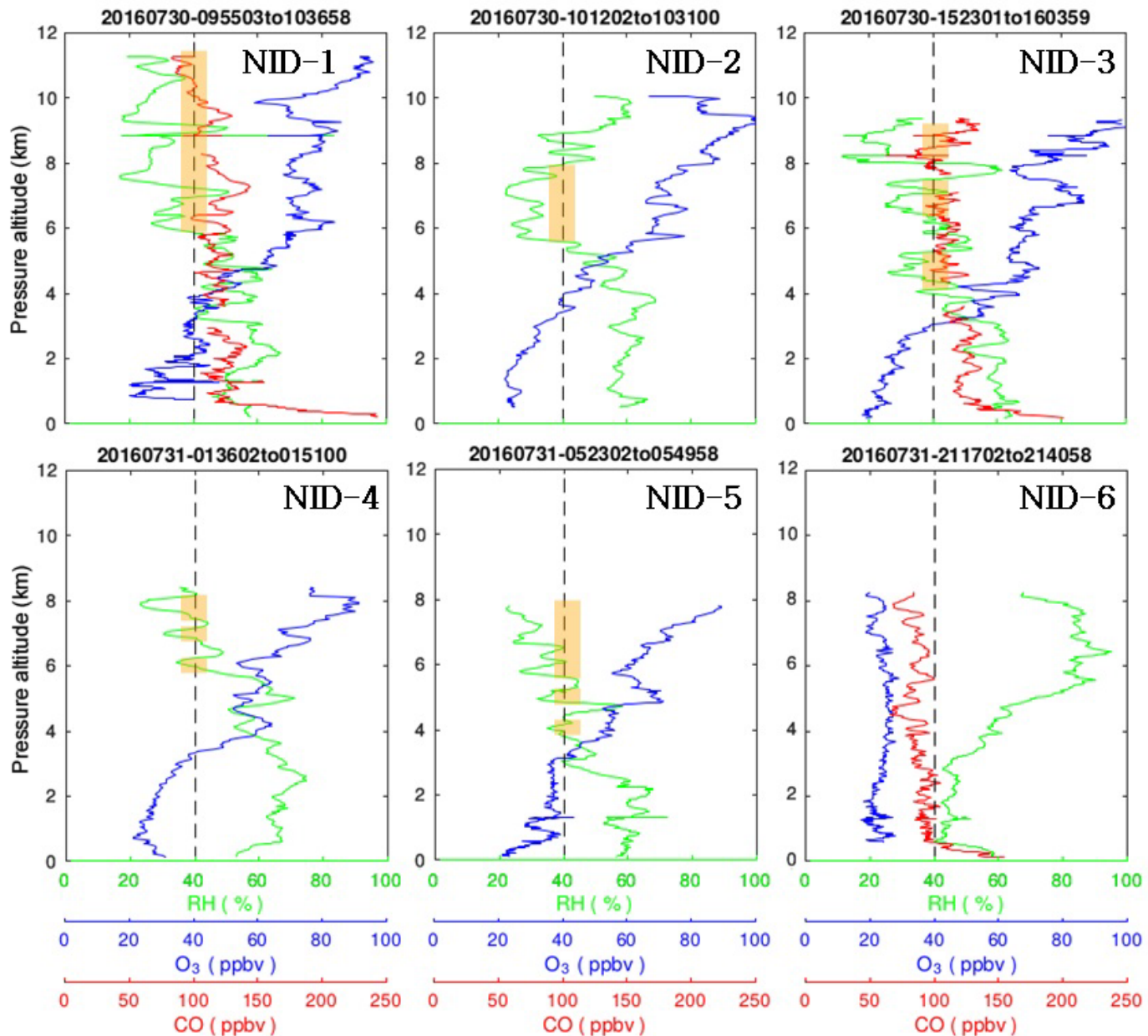

Figure 9. As in Fig. 6, except for the six take-offs from and landings to TPE of IAGOS aircraft on 30-31 July.

Mean cross sections within $\pm 500 \mathrm{~km}$ along the vertical domain of the IAGOS measurements show that the dry zone was related to an intrusion of high-MPV (>1 PVU) air originating from the lower stratosphere into the troposphere. In both the Nepartak and Nida cases, there is a tongue of high-MPV air downstream of the typhoon. These high MPV values in the upper troposphere at $S>1000 \mathrm{~km}$ are associated with downward motions $\left(<-1 \mathrm{~cm} \mathrm{~s}^{-1}\right)$ between 10 and $15 \mathrm{~km}$ altitude and dry air $(\mathrm{RIH}<40 \%)$ down to $4 \mathrm{~km}$ (Fig. 10c). The low-RH and relatively high-MPV zone moved with Nida on 30-31 July while staying 500 to $1500 \mathrm{~km}$ to the northwest with limited deformation. The high-MPV zone at $500<S<1000 \mathrm{~km}$ is rather associated with the production of positive PV through latent heating and its vertical transport in the core region of Nida.

The vertical profiles NID- 1 to NID-6 from the IAGOS aircraft measurements before the arrival of Nida (Fig. 9) show again that the dry layer aloft was associated with a large ozone content (up to $100 \mathrm{ppbv}$ ). The bottom of the ozonerich layer was between 3 and $4 \mathrm{~km}$ altitude, and its top was higher than $11 \mathrm{~km}$, the flight level of IAGOS aircraft. As with Nepartak, this indicates that the dry and $\mathrm{O}_{3}$-rich zone above 3 to $4 \mathrm{~km}$ altitude with $\mathrm{CO}$ values much smaller than in the surface layer did not result from the upward transport of polluted boundary layer air but more likely from stratosphereto-troposphere inflow revealed by the potential vorticity, relative humidity and vertical velocity fields (Fig. 10c and d). Again, backward plumes of particles initiated on 31 July at 00:00 UTC within $24-26^{\circ} \mathrm{N}, 120-122^{\circ} \mathrm{E}(4-10 \mathrm{~km})$, reveal a probable stratospheric origin of the dry and ozone-rich air 110 to $140 \mathrm{~h}$ before initial time (Fig. 11).

Profile NID-6, in the more humid region to the northeast of Nida (Fig. 10c), shows a much lower ozone content $(<30 \mathrm{ppbv})$ and more humid air, along with $\mathrm{CO}$ values less than $100 \mathrm{ppbv}$ throughout the free troposphere up to $8 \mathrm{~km}$ altitude. This profile is similar to profile NEP-5 (and NEP-6, except near $6 \mathrm{~km}$ ) in Fig. 6 from the area near Nepartak. Profile NID-6 appears to encounter the tongue of higherMPV air (>0.5 PVU; Fig. 10d) indicated by the ERA-5 analyses, but IAGOS instruments have not detected an increase in 
(a)

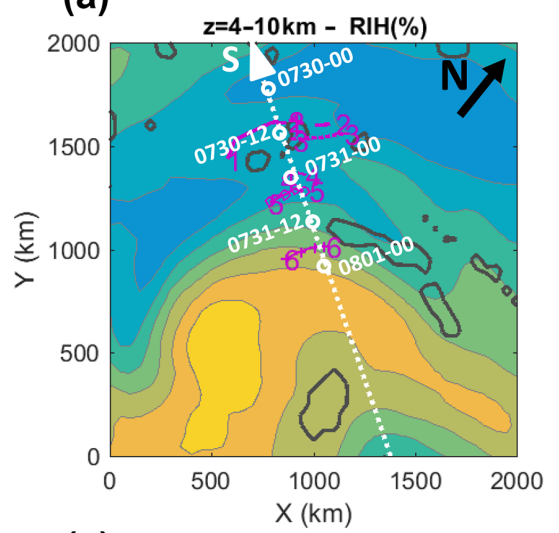

(c)
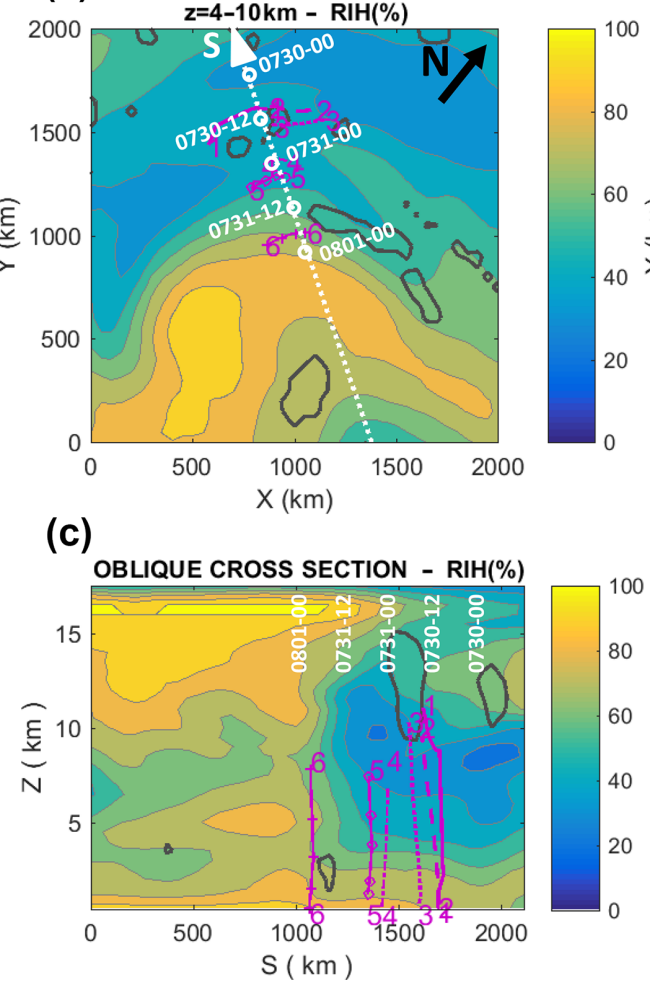

(b)

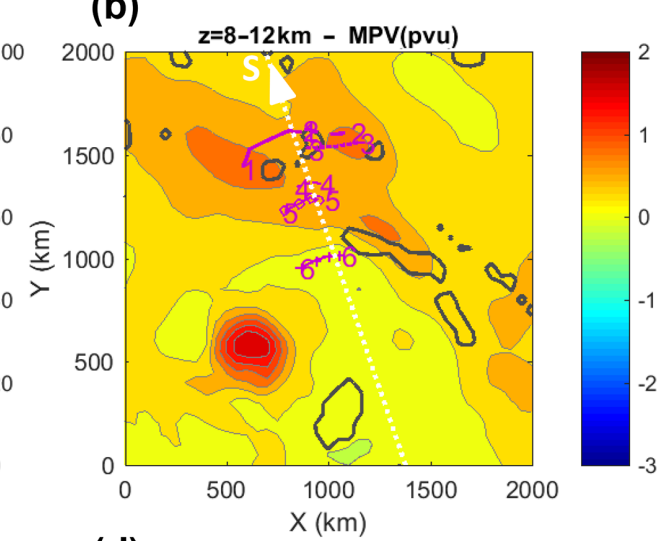

(d)

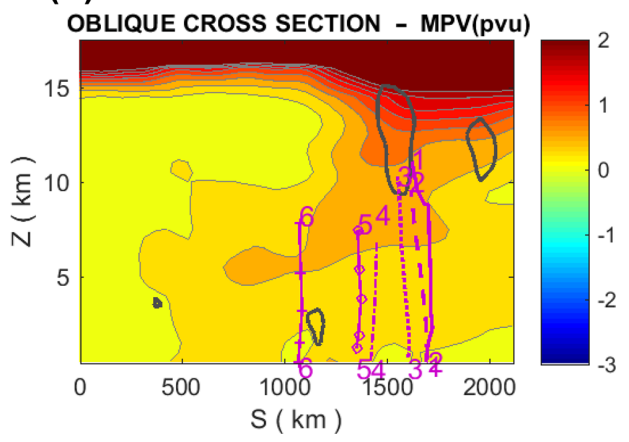

Figure 10. As in Fig. 7, except for the domain shown in Fig. 5b, the period 30 July at 06:00 UTC-1 August at 00:00 UTC, and six tracks of IAGOS aircraft during take-offs and landings on 30-31 July in the vicinity of Severe Tropical Storm Nida.

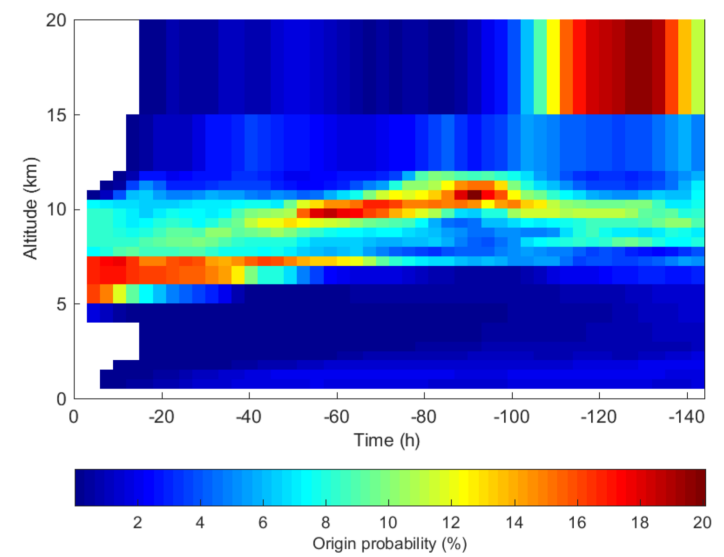

Figure 11. As in Fig. 8, except for the initial time 31 July at 00:00 UTC.

ozone. The correlation with high relative humidity ( $>80 \%)$ suggests that this high-PV air probably originated from the cyclonic circulation associated with Nida.

\subsection{Typhoon Megi on 25-26 September 2016}

Originating from a tropical disturbance northeast of Pohnpei $\left(6.88^{\circ} \mathrm{N}, 158.23^{\circ} \mathrm{E}\right)$ on 19 September, Megi was identified as a tropical storm on 23 September and upgraded to a typhoon on 24 September. After a pause in its development on 25 September, Megi strengthened again on 26 September in the afternoon (Fig. 5c). It reached its maximum intensity on 27 September at 00:00 UTC, with $10 \mathrm{~min}$ averaged winds up to $155 \mathrm{~km} \mathrm{~h}^{-1}\left(\approx 45 \mathrm{~m} \mathrm{~s}^{-1}\right)$ and central pressure at $945 \mathrm{hPa}$, before it made landfall on the eastern coast of Taiwan at 06:00 UTC. Weakened by the interaction with the Central Mountain Range, Megi emerged into the Taiwan Strait in the early afternoon. It made final landfall over mainland China near Xiamen, Fujian province, in the evening of 27 September.

We use the IAGOS observations at TPE from 25 September at 14:12 UTC to 26 September at 16:04 UTC (Fig. 12). The profiles were put into their meteorological context derived from the combination of 6-hourly ERA-5 reanalyses from 25 September at 12:00 UTC to 26 September at 18:00 UTC in the reference frame moving with Megi, at $5.5 \mathrm{~m} \mathrm{~s}^{-1}$ towards $300^{\circ}$ with its origin at $12.76^{\circ} \mathrm{N}, 124.5^{\circ} \mathrm{E}$, on 6 July at 00:00 UTC. Relative integrated humidity between 4 and $10 \mathrm{~km}$ altitude (Fig. 13a) shows the central and eastern parts of Megi with RIH $\geq 80 \%$ and a large region of dry air $(\mathrm{RIH} \leq 40 \%)$ to the north. The MPV field (Fig. 13b) reveals large positive values ( $>2 \mathrm{PVU})$ in the upper core region of Megi and a band of weaker positive 

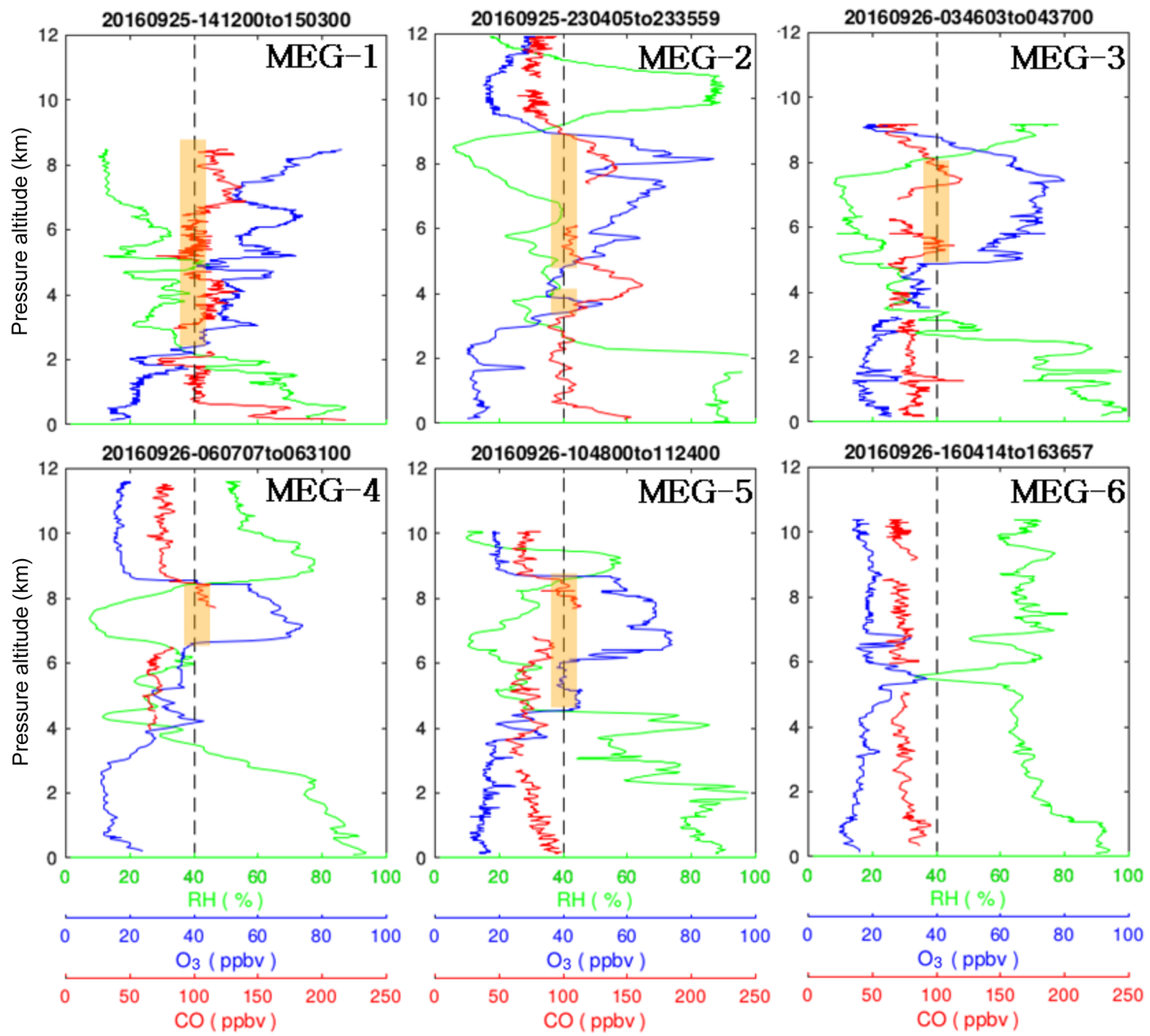

Figure 12. As in Fig. 6, except for the six take-offs from and landings to TPE of IAGOS aircraft on 25-26 September.

values ( $>0.5 \mathrm{PVU})$ in the dry zone to the west of Megi, where mean downward motions $<-1 \mathrm{~cm} \mathrm{~s}^{-1}$ between 6 and $10 \mathrm{~km}$ are also observed. The Taipei radiosounding data (not shown) indicate that the cold-point tropopause descended from $17.3 \mathrm{~km}$ on 25 September at 00:00 UTC to $16.1 \mathrm{~km}$ on 26 September at 00:00 UTC and then went up to $16.8 \mathrm{~km}$ on 27 September at 00:00 UTC.

Mean cross sections within $\pm 500 \mathrm{~km}$ along the vertical domain where IAGOS measurements were made (see $S$ axis in Fig. $13 \mathrm{c}$ and d) show that the dry zone was related to an intrusion of air with relatively high potential vorticity (>1 PVU) from the lower stratosphere into the troposphere (Fig. 13d). These MPV values in the upper troposphere were associated with downward motion $\left(<-1 \mathrm{~cm} \mathrm{~s}^{-1}\right)$ down to $5 \mathrm{~km}$ altitude and dry air $(\mathrm{RIH}<40 \%)$ down to $2 \mathrm{~km}$ (Fig. 13c). The low-RH and relatively high-MPV zone moved without much deformation while staying 500 to $1500 \mathrm{~km}$ to the north of Megi on 26-27 September. Backward plumes of particles initiated within $24-26^{\circ} \mathrm{N}, 120-122^{\circ} \mathrm{E}$ (5-9 km; not shown), reveal that the air parcels originate from the upper troposphere (6-12 km altitude), with a weak contribution from the stratosphere above $16 \mathrm{~km}$ altitude. However, when considering only the layer sampled by IAGOS flight MEG-4 between 6 and $8 \mathrm{~km}$ altitude (Fig. 12), the back trajectories (Fig. 14) show that the probability that the associated air parcels have their origin above $12 \mathrm{~km}$ altitude is larger than 0.25 between 50 and $100 \mathrm{~h}$ before the initial time.

The vertical profiles MEG- 1 to MEG- 6 deduced from the IAGOS aircraft measurements (Fig. 12) reveal that the dry layer aloft was associated with a relatively large ozone content (up to $80 \mathrm{ppbv}$ ), though it was lower than the $100 \mathrm{ppbv}$ seen for Nida and Nepartak. The bottom of this layer was at about $2 \mathrm{~km}$ altitude for the first profile MEG-1, and it increased thereafter up to 5-6 km, whereas its top remained at a nearly constant altitude of $9 \mathrm{~km}$. Similar to the profiles NEP-5, NEP-6 and NID-5, the MEG-6 profile, in the more humid region close to Megi, has a much lower ozone content $(<30 \mathrm{ppbv})$ and more humid air from the surface up to $9 \mathrm{~km}$ altitude, except for a small spike of ozone and dry air at $5.5 \mathrm{~km}$ altitude, which represents the southern limit of the dry and ozone-rich layer (Fig. 13c). Again, the CO content in this layer is significantly weaker than the values up to 150 
(a)

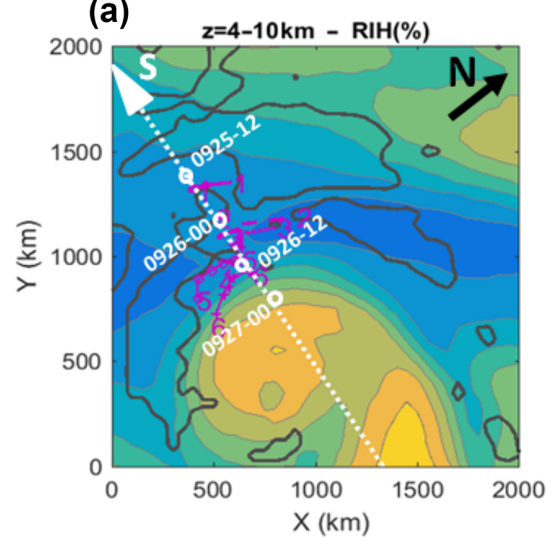

(c)
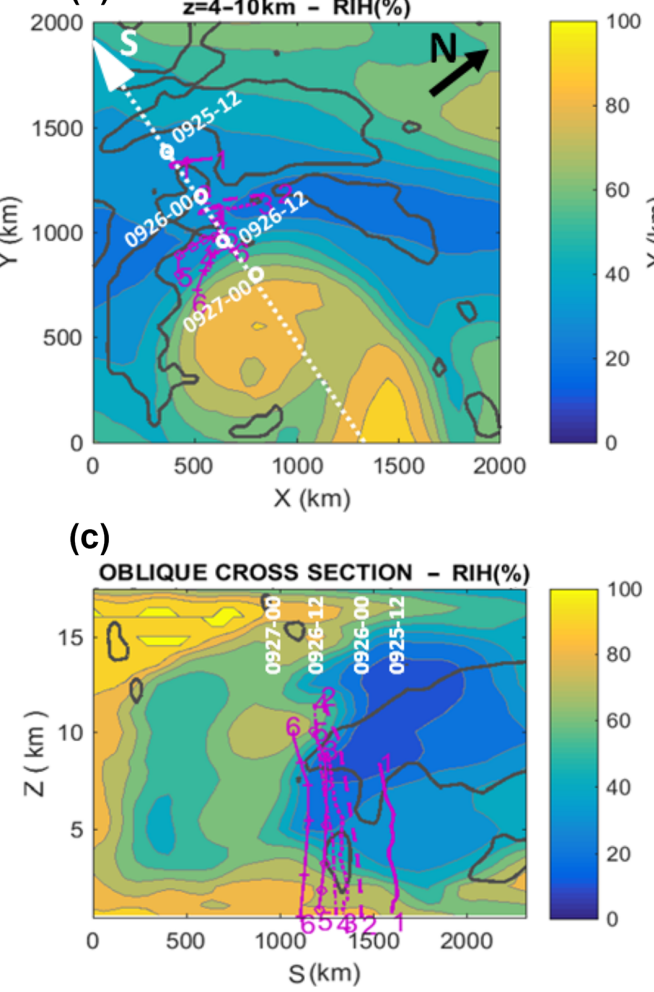

(b)

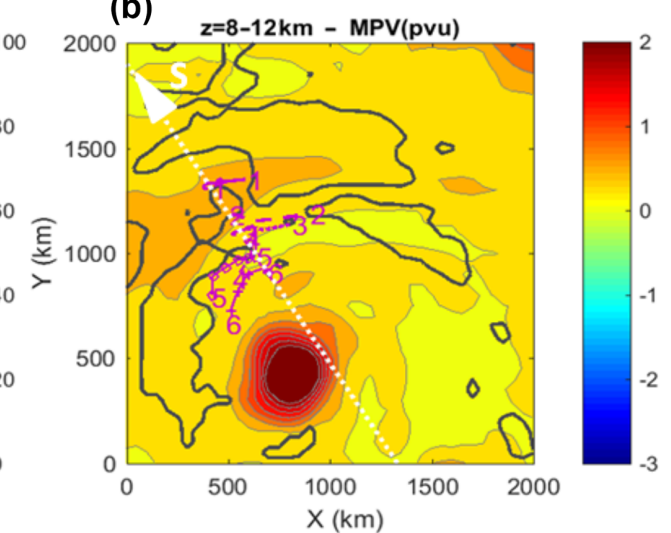

(d)

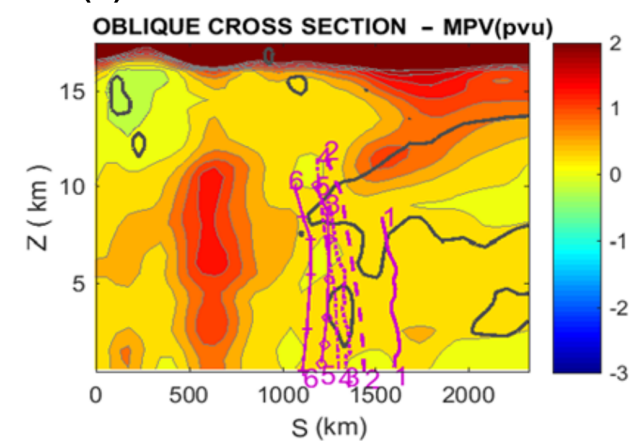

Figure 13. As in Fig. 7, except for the domain shown in Fig. 5c, in the period 25 September at 12:00 UTC to 26 September at 18:00 UTC, and six tracks of IAGOS aircraft during take-offs and landings on 25-26 September in the vicinity of Typhoon Megi.

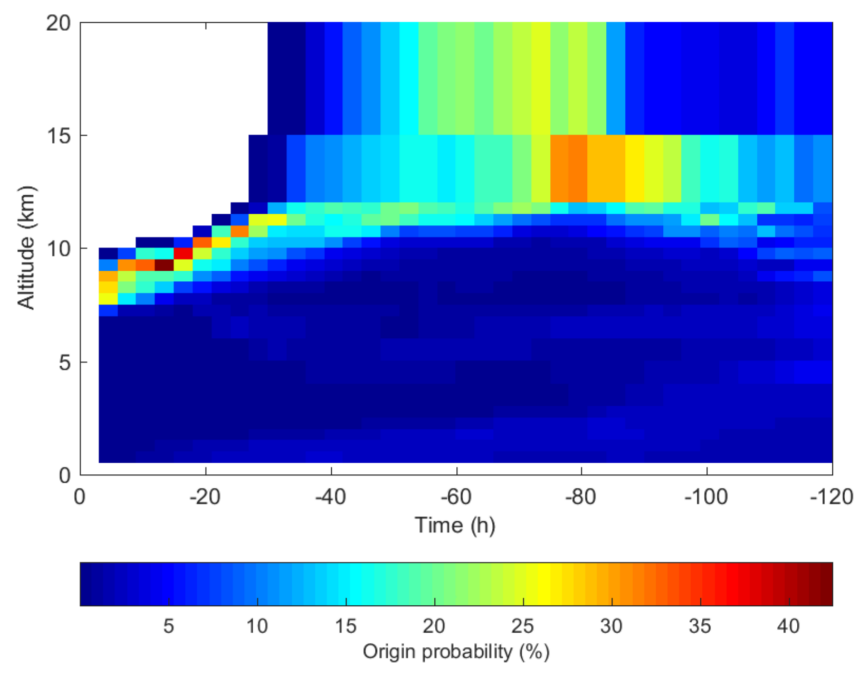

Figure 14. As in Fig. 8, except for the domain $24-25^{\circ} \mathrm{N}, 121.5-$ $122.5^{\circ} \mathrm{E}(6.5-8.5 \mathrm{~km}$ altitude), on 16 September at 06:15 UTC.

200 ppbv observed near the surface, which suggests that the dry, ozone-rich layer did not result from the upward transport of polluted boundary layer air but more likely from the stratosphere-to-troposphere inflow revealed by potential vorticity, relative humidity and vertical velocity fields (Fig. 13c and d). As observed for Nepartak (Fig. 6), one can also note the substantial decrease in $\mathrm{CO}$ content below $1 \mathrm{~km}$ altitude between the first three profiles, from $>200 \mathrm{ppbv}$ for MEG-1 to $\approx 150 \mathrm{ppbv}$ for MEG-2 and $<100 \mathrm{ppbv}$ for MEG-3. This probably denotes the replacement of polluted pre-typhoon air by cleaner oceanic air feeding Typhoon Megi.

\section{Discussion}

The structures of relative humidity, vertical velocity and potential vorticity were also deduced from ERA-5 data for the typhoons Meranti, Malakas, Sarika and Haima (not shown) and were broadly similar to those observed for Nepartak, Nida and Megi. The less favourable coverage by IAGOS aircraft for these typhoons, which passed at a larger distance, from Taiwan did not permit such detailed comparisons of the $\mathrm{O}_{3}$ and $\mathrm{CO}$ profiles. Generally, a tongue of high-PV air and air which is richer in ozone is observed ahead of the typhoons. Dry zones $(\mathrm{RH}<40 \%)$, which could also be identified in Himawari-8 images in the water vapor channels and were associated with downward motion $\left(<-1 \mathrm{~cm} \mathrm{~s}^{-1}\right)$, were systematically found 500 to $1000 \mathrm{~km}$ ahead or to the northwest of the storms when they approached Taiwan over the Philippine Sea, the Luzon Strait and the South China Sea. The associated potential vorticity signature was more vari- 
able, with a very strong signal ( $>1$ PVU down to an altitude of $7 \mathrm{~km}$ ) for Malakas on 16 September 2016, a significant signature ( $>0.5$ PVU down to an altitude of $8 \mathrm{~km}$ ) for Sarika on 16-17 October 2016, and weaker signatures (0-0.5 PVU above $10 \mathrm{~km}$ altitude) for Meranti on 11-13 September 2016 and Haima on 19-20 October 2016. These dry subsiding zones associated with the seven typhoons that passed close to Taiwan in 2016 were not directly related to the mid-latitude westerly circulation, since - when present - the upper-level jet $\left(>40 \mathrm{~m} \mathrm{~s}^{-1}\right)$ was always located between 35 and $40^{\circ} \mathrm{N}$ over northern China, Korea or Japan, about $1500 \mathrm{~km}$ north to northeast of Taiwan. In contrast, closer to the centre, air is reduced in ozone and more humid, consistent with arrival of marine boundary layer air. This is also a repeated feature of the typhoons.

Our results on the influence of tropical cyclones on tropospheric ozone near Taiwan and southern China are comparable with observations over the southwestern and northern Indian Ocean. For example, a radiosonde launched from Saint-Denis, Réunion Island, on 6 April 1995, showed high levels of ozone (>50 ppbv between 500 and $150 \mathrm{hPa}$ ) and low relative humidity $(<30 \%$ above $500 \mathrm{hPa}$ level). Baray et al. (1999) attributed this to subsidence in the upper troposphere to the west of Tropical Cyclone Marlene, whose centre was about $1000 \mathrm{~km}$ to the east of the island. The dry and ozone-rich layer in the upper troposphere corresponded to a relative maximum of PV in the analyses by two general circulation models with horizontal resolution of $2.5^{\circ}$ (National Center for Environmental Predictions - NCEP and National Center for Atmospheric Research - NCAR) and $1.125^{\circ}$ (ECMWF). However these resolutions were too coarse to allow explicit determination of the origin of this $\mathrm{PV}$ maximum. A complementary numerical simulation using the MesoNH model (Lafore et al., 1998) at higher resolution $(45 \mathrm{~km})$ by Leclair de Bellevue et al. (2007) showed that, on 6 April 1995, Réunion Island was under a stratospheric PV filament ( $>1 \mathrm{PVU}$ ) in the troposphere, crossing the isentropes down to the $350 \mathrm{~K}$ level $(\approx 200 \mathrm{hPa})$. This feature was probably related to upper-tropospheric zones of divergence and convergence organized as rings from the centre to the periphery of the cyclone.

Das (2009) reported evidence of stratospheric intrusion into troposphere, identified as enhanced signal-to-noise ratio of thickness $\approx 1 \mathrm{~km}$ between 13 and $16 \mathrm{~km}$ altitude with the mesosphere-stratosphere-troposphere (MST) radar at Gadanki $\left(13.46^{\circ} \mathrm{N}, 79.18^{\circ} \mathrm{E}\right.$; Andhra Pradesh, India) on 16 October 2001. The same day, Cyclonic Storm BoB-01, with a Dvorak rating of 2.5, made landfall near Nellore, about $150 \mathrm{~km}$ northeast of Gadanki. Das et al. (2011) investigated this event with a numerical simulation with the Advanced Research Weather Research and Forecasting (WRF-ARW; Skamarock et al., 2005) model at a horizontal resolution of $27 \mathrm{~km}$. Analysis of vertical velocity and PV revealed that the stratospheric intrusion occurred in the periphery of the cyclone centre. The horizontal and vertical scales of the intru- sion were 200-250 and 5-6 km, respectively, with a width of about $50 \mathrm{~km}$.

More recently, Das et al. (2016) analysed series of ozonesondes launched from Trivandrum $\left(8.51^{\circ} \mathrm{N}, 76.96^{\circ} \mathrm{E}\right.$; Kerala, India) during two cyclone events from the Bay of Bengal: Cyclonic (tropical) Storm Nilam from 30 October to 7 November 2012 and very severe Cyclonic Storm (equivalent to a Category 1 hurricane) Phailin from 11 to 15 October 2013. Both events were associated with an increase in the upper-tropospheric $(10-16 \mathrm{~km})$ ozone, which propagated downward at a rate of about $-1 \mathrm{~cm} \mathrm{~s}^{-1}$. WRF-ARW simulations revealed that these ozone-rich zones were associated with enhanced PV values ( 0.5 to $1.5 \mathrm{PVU}$ ) overlapping the downdraft regions and extending vertically down from the stratosphere to the lower troposphere. The simultaneous presence of dry air from the tropopause level down to $4 \mathrm{~km}$ altitude was an additional indication of descent of stratospheric air into the troposphere, induced by the tropical cyclones.

Jiang et al. (2015) reported large increases in surface ozone between Xiamen and Quanzhou from 12 to 14 June 2014, before Typhoon Hagibis made landfall over the southeastern coast of China early on 15 June. Weak easterly winds carrying clear air from the ocean, low nitrogen oxide concentrations, and negative correlation between ozone and carbon monoxide suggested that the surface ozone peak was unlikely caused by horizontal advection from anthropogenic sources. Vertical velocities from NCEP analyses and dry surface air provided indications of strong downward transport of ozone in a subsiding branch about $400 \mathrm{~km}$ to the northeast of Typhoon Hagibis centre, over the Xiamen-Quanzhou region.

These studies showed that a strong cyclone-driven intrusion of stratospheric air can transport ozone down to the low troposphere and the surface and lead to noticeable anomalies in its concentrations. It is also possible to establish a parallel between these observations and the report by Pan et al. (2014) of ozone-rich stratospheric air wrapping around both leading and trailing edges of a mesoscale convective system and descending down to an altitude of $8 \mathrm{~km}$, about $4 \mathrm{~km}$ below the local tropopause level.

\section{Conclusion and perspectives}

Figure 15 shows a schematical cross section of a model typhoon (or tropical cyclone) and the different ways it can modify the chemical characteristics of the troposphere. The results presented here, and those by some of the authors quoted above, relate mostly to one specific process: uppertropospheric-lower-stratospheric intrusion identified by correlations between high ozone and low carbon monoxide contents, downward motions, dry relative humidity, and relatively high PV values. Although it has been documented on several occasions, it is not clear whether such a phenomenon which occurs 500 to $1000 \mathrm{~km}$ from the centre of the storm 


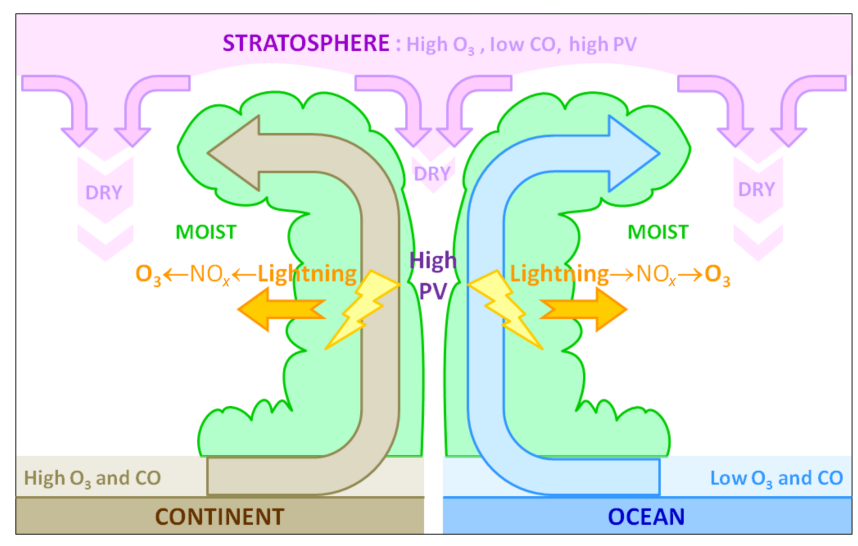

Figure 15. A schematic cross section (not to scale) of a model typhoon and associated transports of ozone and carbon monoxide in relation to dry and moist regions and high-potential-vorticity zones (see text).

is a frequent feature associated with tropical cyclones worldwide.

We have also seen that the upward transport of clean humid air from the oceanic boundary layer decreases the tropospheric ozone content. Other processes schematically represented in Fig. 15 can also influence the chemical characteristics of the troposphere in the vicinity of tropical cyclones. Several authors have shown that ozone and carbon monoxide would increase when the inflow is at least partially from polluted continental areas. In the cases that we have presented, the pollution generally remained in the boundary layer below $1 \mathrm{~km}$. Subsidence above the eye could also carry stratospheric ozone into the upper troposphere, but the concerned region has a relatively limited area, and this process might not be very efficient at the storm scale. Commercial flights carrying the IAGOS instruments would never fly in such a hazardous region. Lightning associated with intense convection in the eyewall and the external rainbands produce nitrogen oxides and ozone, which is then advected horizontally and vertically. However, the relationship between tropical cyclones and lightning activity is complex, and it is not certain that this mechanism represents a major contribution to the ozone budget for the majority of storms.

It is therefore necessary to continue the sampling of tropospheric ozone (and carbon monoxide) profiles in the vicinity of tropical cyclones to draw statistically and climatologically reliable figures. The fact that IAGOS aircraft from China Airlines operate from the TPE airport is an excellent opportunity, considering the frequent occurrence of typhoons in the vicinity of Taiwan. IAGOS offers additional instrumentation to measure $\mathrm{NO}_{x}$, which is available on one aircraft so far (Berkes et al., 2018). In future it is hoped that $\mathrm{NO}_{x}$ instruments on China Airlines could help to determine the amount of lightning $\mathrm{NO}_{x}$ produced in the vicinity of typhoons. Of course, it would also be necessary to obtain similar infor- mation for storms over other basins to examine whether the observed characteristics relate to the cyclone structure and evolution or to some specificity of their environment. Additional information might also come from numerical simulations with high-resolution models explicitly representing convective dynamics, microphysics, electrification and lightning (e.g. Fierro et al., 2011; Xu et al., 2014; Barthe et al., 2016) as well as the associated production and transport of nitrogen oxides and ozone. It would also be necessary to represent correctly the troposphere-stratosphere interactions associated with tropical cyclones at local scales and mesoscales (e.g. Dauhut et al., 2018). Such results would help to quantify more precisely the global contribution of tropical cyclones to the chemistry budget of the troposphere.

Code availability. The MATLAB scripts used to analyse the ERA5 data (netCDF files formatted by ClimServ) are available at https: //mycore.core-cloud.net/index.php/s/vi2SmsVJNVnM4w0 (Roux, 2020a) (“coupe_zt_era5.txt" and "coupe_zt_era5.m" were used to obtain Fig. 3). The MATLAB scripts used to analyse the IAGOS data (netCDF files formatted by IAGOS Data Portal) are available at https://mycore.core-cloud.net/index.php/s/JWmep21ghplwUG1 (Roux, 2020b) ("juloct.m" was used to obtain Fig. 2; "tra_rho3co.txt" and "tra_rho3co.m" were used to obtain Figs. 7, 10 and 13). The MATLAB scripts used to simultaneously analyse ERA-5 and IAGOS data (in netCDF formats) are available at https://mycore.core-cloud.net/index.php/s/dscfB8XUqLaw3Pv (Roux, 2020c) ("rhpvw_era5_sv_meanbox.txt" and "rhpvw_era5_sv_meanbox.m" were used to obtain Figs. 6, 9 and 12).

Data availability. The ERA-5 data were obtained through the ClimServ Data Portal at http://climserv.ipsl.polytechnique.fr/ (Instiitut Pierre Simon Laplace IPSL. Laboratoire de Météorologie Dynamique, 2020). The IAGOS data were obtained through the IAGOS Data Portal at http://www.iagos-data.fr (Clark et al., 2020).

Author contributions. FR, HC, KYW, SR, BS and PN conceived the project, devised the main conceptual ideas, and reviewed the literature. FR designed and performed the numerical calculations. $\mathrm{HC}$ and FR analysed the results and wrote the paper. FR, HC, KYW, $\mathrm{SR}, \mathrm{BS}$ and PN conducted a critical review.

Competing interests. The authors declare that they have no conflict of interest.

Acknowledgements. IAGOS is funded by the European Union projects IAGOS-DS and IAGOS-ERI. The IAGOS database is supported in France by AERIS (Centre National d'Etudes Spatiales and Institut National des Sciences de l'Univers and Centre National de la Recherche Scientifique). We acknowledge the strong support of the European Commission, Airbus and the airlines (Lufthansa, Air 
France, Austrian Airlines, Air Namibia, Cathay Pacific, Iberia and China Airlines so far) that carry the IAGOS equipment.

ERA-5 reanalyses data were obtained from ClimServ (http: //climserv.ipsl.polytechnique.fr/, last access: 31 March 2020), a French open-access service developed by the Laboratoire de Météorologie Dynamique (Paris) and maintained by Institut Pierre Simon Laplace, for studies related to climate, atmospheric processes, and technical and scientific analyses of Earth-observing satellite data.

Himawari-8 geostationary satellite images in Fig. 5 were downloaded and are reproduced with permission from the NERC Satellite Receiving Station, University of Dundee, Scotland (http://www.sat. dundee.ac.uk/, last access: 20 November 2018).

We are indebted to Laura L. Pan and an anonymous reviewer for their helpful comments on a previous version of the paper.

Review statement. This paper was edited by Timothy J. Dunkerton and reviewed by Laura Pan and one anonymous referee.

\section{References}

Akritidis, D., Katragkou, E., Zanis, P., Pytharoulis, I., Melas, D., Flemming, J., Inness, A., Clark, H., Plu, M., and Eskes, H.: A deep stratosphere-to-troposphere ozone transport event over Europe simulated in CAMS global and regional forecast systems: analysis and evaluation, Atmos. Chem. Phys., 18, 15515-15534, https://doi.org/10.5194/acp-18-15515-2018, 2018.

Baray, J.-L., Ancellet, G., Randriambelo, T., and Baldy, S.: Tropical cyclone Marlene and Stratosphere-Troposphere Exchange, J. Geophys. Res., 104, 13953-13970, https://doi.org/10.1029/1999JD900028, 1999.

Barthe, C., Hoarau, T., and Bovalo, C.: Cloud electrification and lightning activity in a tropical cyclone-like vortex, Atmos. Res., 180, 297-309, https://doi.org/10.1016/j.atmosres.2016.05.023, 2016.

Berkes, F., Houben, N., Bundke, U., Franke, H., Pätz, H.-W., Rohrer, F., Wahner, A., and Petzold, A.: The IAGOS $\mathrm{NO}_{x}$ instrument - design, operation and first results from deployment aboard passenger aircraft, Atmos. Meas. Tech., 11, 3737-3757, https://doi.org/10.5194/amt-11-3737-2018, 2018.

Brioude, J., Cammas, J.-P., and Cooper, O. R.: Stratospheretroposphere exchange in a summertime extratropical low: Analysis, Atmos. Chem. Phys., 6, 2337-2353, https://doi.org/10.5194/acp-6-2337-2006, 2006.

Cairo, F., Buontempo, C., MacKenzie, A. R., Schiller, C., Volk, C. M., Adriani, A., Mitev, V., Matthey, R., Di Donfrancesco, G., Oulanovsky, A., Ravegnani, F., Yushkov, V., Snels, M., Cagnazzo, C., and Stefanutti, L.: Morphology of the tropopause layer and lower stratosphere above a tropical cyclone: a case study on cyclone Davina (1999), Atmos. Chem. Phys., 8, 34113426, https://doi.org/10.5194/acp-8-3411-2008, 2008.

Chen, Y.-H., Kuo, H.-C., Wang, C.-C., and Yi-Ting Yang, Y.-T.: Influence of southwest monsoon flow and typhoon track on Taiwan rainfall during the exit phase: modelling study of typhoon Morakot (2009), Q. J. Roy. Meteor. Soc., 143, 3014-3024, https://doi.org/10.1002/qj.3156, 2015.
Chow, E. C. H., Li, R. C. Y., and Zhou, W.: Influence of tropical cyclones on Hong Kong air quality, Adv. Atmos. Sci., 35, 11771188, https://doi.org/10.1007/S00376-018-7225-4, 2018.

Clark, H. L., Sauvage, B., Thouret, V., Nédélec, P., Blot, R., Wang, K.-Y., Smit, H., Neis, P., Petzold, A., Athier, G. , Boulanger, D., Cousin, J.-M., Beswick, K., Gallagher, M., Baumgardner, D., Kaiser, J., Flaud, J.-M., Wahner, A., Volz-Thomas, A., and Cammas, J.-P.: The first regular measurements of ozone, carbon monoxide and water vapour in the Pacific UTLS by IAGOS, Tellus B, 67, 28385, https://doi.org/10.3402/tellusb.v67.28385, 2015.

Clark, H., Petzold, A., Thouret, V., and Zahn, A.: IAGOS data, available at: http://www.iagos-data.fr, last access: 31 March 2020.

Das, S. S.: A new perspective on MST radar observation of stratospheric intrusions into troposphere associated with tropical cyclone, Geophys. Res. Lett., 36, L15821, https://doi.org/10.1029/2009GL039184, 2009.

Das, S. S., Sijikumar, S., and Uma, K. N.: Further investigation on stratospheric air intrusion into the troposphere during the episode of tropical cyclone: Numerical simulation and MST radar observations, Atmos. Res., 101, 928-937, https://doi.org/10.1016/j.atmosres.2011.05.023, 2011.

Das, S. S., Ratnam, M. K., Uma, K. N., Subrahmanyam, K. V., Girach, I. A., Patra, A. K., Aneesh, S., Suneeth, K. V., Kumar, K. K., Kesarkar, A. P., Sijikumar, S., and Ramkumar, G.: Influence of tropical cyclones on tropospheric ozone:Possible implications, Atmos. Chem. Phys., 16, 48374847, https://doi.org/10.5194/acp-16-4837-2016, 2016.

Dauhut, T., Chaboureau, J., Haynes, P. H., and Lane, T. P.: The Mechanisms leading to a stratospheric hydration by overshooting convection, J. Atmos. Sci., 75, 4383-4398, https://doi.org/10.1175/JAS-D-18-0176.1, 2018.

Dee, D. P., Uppala, S. M., Simmons, A. J., Berrisford, P., Poli, P., Kobayashi, S., Andrae, U., Balmaseda, M. A., Balsamo, G., Bauer, P., Bechtold, P., Beljaars, A. C. M., van de Berg, L., Bidlot, J., Bormann, N., Delsol, C., Dragani, R., Fuentes, M., Geer, A. J., Haimberger, L., Healy, S. B., Hersbach, H., Holm, E. V., Isaksen, L., Kâllberg, Köhler, M., Matricardi, M., McNally, A. P., Monge-Sanz, B. M., Morcrette, J.-J., Park, B.-K., Peubey, C., de Rosnay, P., Tavolato, C., Thépaut, J.-N., and Vitart, F.: The ERA-Interim Reanalysis: Configuration and Performance of the Data Assimilation System, Q. J. Roy. Meteor. Soc., 137, 553597, https://doi.org/10.1002/qj.828, 2011.

De Forster, P. M. F. and Shine, K. P.: Radiative forcing and temperature trends from stratospheric ozone changes, J. Geophys. Res., 102, 10841-10855, https://doi.org/10.1029/96JD03510, 1997.

DeMaria, M., DeMaria, R. T., Knaff, J. A., and Molenar, D.: Tropical cyclone lightning and rapid intensity change, Month. Weather Rev., 140, 1828-1842, https://doi.org/10.1175/MWRD-11-00236.1, 2012.

Feng, Y., Wang, A., Wu, D., and Xu, X.: The influence of tropical cyclone Melor on $\mathrm{PM}_{10}$ concentrations during an aerosol episode over the Pearl River Delta region of China:Numerical modeling versus observational analysis, Atmos. Environ., 41, 4349-4365, 2007.

Fierro, A. O. and Reisner, J. M.: High-resolution simulation of the electrification and lightning of Hurricane Rita during the 
period of rapid intensification, J. Atmos. Sci., 68, 477-494, https://doi.org/10.1175/2010JAS3659.1, 2011.

Gettelman, A., de Forster, P. M. F., Fujiwara, M., Fu, Q., Vömel, H., Gohar, L. K., Johanson, C., and Ammerman, M.: Radiation balance of the tropical tropopause layer, J. Geophys. Res., 109, D07103, https://doi.org/10.1029/2003JD004190, 2004.

Gettelman, A., Hoor, P., Pan, L. L., Randel, W. J., Hegglin, M. I., and Birner, T.: The extratropical upper troposphere and lower stratosphere, Rev. Geophys., 49, RG3003, https://doi.org/10.1029/2011RG000355, 2011.

Gibbins, C. J.: A survey and comparison of relationships for the determination of the saturation vapor pressure over plane surfaces of pure water and of pure ice, Ann. Geophys., 8, 859-886, 1990.

Goff, J. A. and Gratch, S.: Low pressure properties of water from -160 to $+212 \mathrm{~F}$, Transactions of the 52nd Annual Meeting of the American Society of Heating and Ventilating Engineers, Murray bay, Québec, Canada, 95-102, 1946.

Hegglin, M. I., Boone, C. D., Manney, G. L., and Walker, K. A.: A global view of the extratropical tropopause transition layer from Atmospheric Chemistry Experiment Fourier Transform Spectrometer $\mathrm{O}_{3}, \mathrm{H}_{2} \mathrm{O}$, and CO, J. Geophys. Res., 114, D00B11, https://doi.org/10.1029/2008JD009984, 2009.

Hersbach, H. and Dee, D.: ERA-5 reanalysis is in production, ECMWF Newsletter, 147, 7 pp., 2016.

Holton, J. R., Haynes, P. H., McIntyre, M. E., Douglass, A. R., Rood, R. B., and Pfister, L.: Stratospheretroposphere exchange, Rev. Geophys., 33, 403-439, https://doi.org/10.1029/95RG02097, 1995.

Hoor, P., Fischer, H., Lange, L., and Lelieveld, J.: Seasonal variations of a mixing layer in the lowermost stratosphere as identified by the $\mathrm{CO}-\mathrm{O}_{3}$ correlation from in situ measurements, J. Geophys. Res, 107, 4044, https://doi.org/10.1029/2000JD000289, 2002

Huang, J.-P., Fung, J. C. H., Lau, A. K. H., and Qin, Y.: Numerical simulations and process analysis of typhoon-related ozone episodes in Hong Kong, J. Geophys. Res., 110, D05301, https://doi.org/10.1029/2004JD004914, 2005.

Hung, C.-H. and Lo, K.-C.: Relationship between ambient ozone concentration changes in southwestern Taiwan and invasion tracks of tropical typhoons, Adv. Meteorol., 2015, 402976, https://doi.org/10.1155/2015/402976, 2015.

Instiitut Pierre Simon Laplace IPSL. Laboratoire de Météorologie Dynamique: ERA-5 data, available at: http://climserv.ipsl. polytechnique.fr/, last access: 31 March 2020.

Jenkins, G. J., Robjhon, M. L., Reyes, A., Valentine, A., and Neves, L.: Elevated middle and upper troposphere ozone observed downstream of Atlantic tropical cyclones, Atmos. Environ., 118, 78-86, 2015.

Jiang, Y. C., Zhao, T. L., Liu, J., Xu, X. D., Tan, C. H., Cheng, X. H., Bi, X. Y., Gan, J. B., You, J. F., and Zhao, S. Z.: Why does surface ozone peak before a typhoon landing in southeast China, Atmos. Chem. Phys., 15, 13331-13338, https://doi.org/10.5194/acp-1513331-2015, 2015.

JTWC Guam: Annual Tropical Cyclone Report 2016, Joint Typhoon Warning Center, United States Air Force and United States Navy, available at: http://www.metoc.navy.mil/jtwc/ products/atcr/2016atcr.pdf (last access: 31 March 2020), 2017.

Lafore, J.-P., Stein, J., Asencio, N., Bougeault, P., Ducrocq, V., Duron, J., Fischer, C., Héreil, P., Mascart, P., Masson, V., Pinty,
J.-P., Redelsperger, J.-L., Richard, E., and Vilà-Guerau de Arellano, J.: The Meso-NH Atmospheric Simulation System, Part I: adiabatic formulation and control simulations. Scientific objectives and experimental design, Ann. Geophys., 16, 90-109, https://doi.org/10.1007/s00585-997-0090-6, 1998.

Leclair de Bellevue, J., Baray, J.-L., Baldy, S., Ancellet, G., Diab, R., and Ravetta, F.: Simulation of stratosphere to troposphere transport during the tropical cyclone Marlene event, Atmos. Environ., 41, 6510-6526, https://doi.org/10.1016/j.atmosenv.2007.04.040, 2007.

Lee, Y. C., Calori, G., Hills, P., and Carmichael, G. R.: Ozone episodes in urban Hong Kong 1994-1999, Atmos. Environ. 36, 1957-1968, https://doi.org/10.1016/S1352-2310(02)001504, 2002.

Lelieveld, J. and Crutzen, P. J.: Role of Deep Cloud Convection in the Ozone Budget of the Troposphere, Science, 264, 1759-1761, https://doi.org/10.1126/science.264.5166.1759, 1994.

Midya, S. K., Dey, S. S., and Chakraborty, B.: Variation of the total ozone column during tropical cyclones over the bay of Bengal and the Arabian Sea, Meteorol. Atmos. Phys., 117, 63-71, https://doi.org/10.1007/s00703-011-0169-1, 2012.

Molinari, J., Skubis, S., Vollaro, D., and Alsheimer, F.: Potential vorticity analysisof tropical cyclone intensification, J. Atmos. Sci., 55, 2632-2644, 1998

Nédélec, P., Blot, R., Boulanger, D., Athier, G., Cousin, J.-M., Gautron, B., Petzold, A., Volz-Thomas, A., and Thouret, V.: Instrumentation on commercial aircraft for monitoring the atmospheric composition on a global scale: the IAGOS system, technical overview of ozone and carbon monoxide measurements, Tellus B, 67, 27791, https://doi.org/10.3402/tellusb.v67.27791, 2015.

Newell, R. E., Hu, W., Wu, Z-X., Zhu, Y., Akimoto, H., Anderson, B. E., Browell, E. V, Gregory, G. L., Sachse, G. W., Shipham, M. C., Bachmeier, A. S., Bandy, A. R., Thornton, D. C., Blake, D R., Rowland, F. S., Bradshaw, J. D., Crawford, J. H., Davis, D. D., Sandholm, S. T., Brockett, W., DeGreef, L., Lewis, D., McCormick, D., Monitz, E., Collins Jr., J. E., Heikes, B. G., Merrill, J. T., Kelly, K. K., Liu, S. C., Kondo, Y., Koike, M., Liu, C.-M., Sakamaki, F., Singh, H. B., Dibb, J. E., and Talbot, R. W.: Atmospheric sampling of Supertyphoon Mireille with NASA DC-8 aircraft on September 27, 1991, during PEM-West A, J. Geophys. Res., 101, 1853-1871, https://doi.org/10.1029/95JD01374, 1996.

Pan, L. L., Homeyer, C. R., Honomochi, S., Ridley, B. A., Weisman, M., Barth, M. C., Hair, J. W., Fenn, M. A., Butler, C., Diskin, G. S., Crawford, J. H., Ryerson, T. B., Pollack, I., Peischl, J., and Huntrieser, H.: Thunderstorms enhance tropospheric ozone by wrapping and shedding stratospheric air, Geophys. Res. Lett., 41, 7785-7790, https://doi.org/10.1002/2014GL061921, 2014.

Penn, S.: Ozone and temperature structure in a hurricane, J. Appl. Meteorol., 4, 212-216, 1965.

Penn, S.: Temperature and ozone variations near the tropopause level over Hurricane Isbell October 1964, J. Appl. Meteorol., 4, 212-216, 1966.

Petzold, A., Thouret, V., Gerbig, C., Zahn, A., Brenninkmeijer, C. A. M., Gallagher, M., Hermann, M., Pontaud, M., Ziereis, H., Boulanger, D., Marshall, J., Nédélec, P., Smit, H. G. J., Friess, U., Flaud, J.-M., Wahner, A., Cammas, J.-P., Volz-Thomas, A., and IAGOS TEAM: Global-scale atmosphere monitoring by in- 
service aircraft - current achievements and future prospects of the European Research Infrastructure IAGOS, Tellus B, 67, 124, https://doi.org/10.3402/tellusb.v67.28452, 2015.

Preston, A., Fuelberg, H., and Berth., M.: Simulation of chemical transport by Typhoon Mireille (1991), J. Geophys. Res.-Atmos., 124, 11614-11639, https://doi.org/10.1029/2019JD030446, 2019.

Ramanathan, V., Callis, L., Cess, R., Hansen, J., Isaksen, I., Kuhn, W., Lacis, A., Luther, F., Mahlman, J., Reck, R., and Schlesinger, M.: Climate-chemical interactions and effects of changing atmospheric trace gases, Rev. Geophys., 25, 14411482, https://doi.org/10.1029/RG025i007p01441, 1987.

Randel, W. J., Rivoire, L., Pan, L. L., and Honmichi, S. B.: Dry layers in the tropical troposphere observed during CONTRAST and global behaviour from GFS analyses, J. Geophys. Res.-Atmos., 121, 14142-14158, https://doi.org/10.1002/2016JD025841, 2016.

Riese, M., Ploeger, F., Rap, A., Vogel, B., Konopka, P., Dameris, M., and Forster, P.: Impact of uncertainties in atmospheric mixing on simulated UTLS composition and related radiative effects, J. Geophys. Res., 117, D16305, https://doi.org/10.1029/2012JD017751, 2012.

Romps, D. M. and Kuang, Z. M.: Overshooting convection in tropical cyclones, Geophys. Res. Lett., 36, L09804, https://doi.org/10.1029/2009GL037396, 2009.

Roux, F.: ERA-5 data processing, available at: https://mycore. core-cloud.net/index.php/s/vi2SmsVJNVnM4w0, last access: 31 March 2020a.

Roux, F.: IAGOS data processing, available at: https: //mycore.core-cloud.net/index.php/s/JWmep21ghplwUG1, last access: 31 March 2020b.

Roux, F.: ERA-5 and IAGOS data processing, available at: https:// mycore.core-cloud.net/index.php/s/dscfB8XUqLaw3Pv, last access: 31 March 2020c.

RSMC Tokyo: Annual Report on the Activities of the RSMC Tokyo - Typhoon Center 2016, Regional Specialized Warning Center, Japan Meteorological Agency, 95 pp., 2017.

Skamarock, W. C., Klemp, J. B., Dudhia, J., Gill, D. O., Barker, D. M., Wang, W., and Power, J. G.: A description of the advanced research WRF Version-2, NCAR Tech. Note 468+STR, National Center for Atmospheric Research, Boulder, Co., USA, 100 pp., https://doi.org/10.5065/D6DZ069T, 2005.

Stohl, A., Bonasoni, P., Cristofanelli, P., Collins, W., Feichter, J., Frank, A., Forster, C., Gerasopoulos, E., Gäggeler, H., James, P., Kentarchos, T., Kromp-Kolb, H., Krüger, B., Land, C., Meloen, J., Papayannis, A., Priller, A., Seibert, P., Sprenger, M., Roelofs, G. J., Scheel, H. E., Schnabel, C., Siegmund, P., Tobler, L., Trickl, T., Wernli, H., Wirth, V., Zanis, P., and Zerefos, C.: Stratosphere-troposphere exchange: A review, and what we have learned from STACCATO, J. Geophys. Res., 108, 8516, https://doi.org/10.1029/2002JD002490, 2003.

Stohl, A., Forster, C., Frank, A., Seibert, P., and Wotawa, G.: Technical note: The Lagrangian particle dispersion model FLEXPART version 6.2, Atmos. Chem. Phys., 5, 2461-2474, https://doi.org/10.5194/acp-5-2461-2005, 2005.
Tilmes, S. , Pan, L. L., Hoor, P., Atlas, E., Avery, M. A., Campos, T., Christensen, L. E., Diskin, G. S., Gao, R.-S., Herman, R. L., Hintsa, E. J., Loewenstein, M., Lopez, J., Paige, M. E., Pittman, J. V., Podolske, J. R., Proffitt, M. R., Sachse, G. W., Schiller, C., Schlager, H., Smith, J., Spelten, N., Webster, C., Weinheimer, A., and Zondlo, M. A.: An aircraft-based upper troposphere lower stratosphere $\mathrm{O}_{3}, \mathrm{CO}$, and $\mathrm{H}_{2} \mathrm{O}$ climatology for the Northern Hemisphere, J. Geophys. Res., 115, D14303, https://doi.org/10.1029/2009JD012731, 2010.

Venkat Ratnam, M., Ravindra Babu, S., Das, S. S., Basha, G., Krishnamurthy, B. V., and Venkateswararao, B.: Effect of tropical cyclones on the stratosphere-troposphere exchange observed using satellite observations over the north Indian Ocean, Atmos. Chem. Phys., 16, 8581-8591, https://doi.org/10.5194/acp16-8581-2016, 2016.

Wei, X., Lam, K.-S., Cao, C., Li, H., and He, J.: Dynamics of the Typhoon Haitang related high ozone episode over Hong Kong, Adv. Meteorol., 2016, 6089154, https://doi.org/10.1155/2016/6089154, 2016.

Xu, L., Zhang, Y., Wang, F., and Zeng, D.: Simulation of the electrification of a tropical cyclone using the WRF-ARW model: An idealized case, J. Meteorol. Res., 28, 453-468, https://doi.org/10.1007/s13351-014-3079-6, 2014.

$\mathrm{Xu}$, W., Rutledge, S. A., and Zhang, W.: Relationships between total lightning, deep convection, and tropical cyclone intensity change, J. Geophys. Res., 122, 7047-7063, https://doi.org/10.1002/2017JD027072, 2017.

Yang, J. X., Lau, A. K. H., Fung, J. C. H., Zhou, W., and Wenig, M.: An air pollution episode and its formation mechanism during the tropical cyclone Nuris's landfall in a coastal city of south China, Atmos. Environ., 54, 746-753, https://doi.org/10.1016/j.atmosenv.2011.12.023, 2012.

Yue, X. and Unger, N.: Ozone vegetation damage effects on gross primary productivity in the United States, Atmos. Chem. Phys., 14, 9137-9153, https://doi.org/10.5194/acp-149137-2014, 2014.

Zhan, R. and Wang, Y.: Contribution of tropical cyclones to stratosphere-troposphere exchange over the northwest Pacific: Estimation based on AIRS satellite retrievals and ERA-Interim data, J. Geophys. Res., 117, D12112, https://doi.org/10.1029/2012JD017494, 2012.

Zhang, W., Leung, Y., and Chan, J. L. C.: The analysis of tropical cyclone tracks in the western North Pacific through data mining, Part I: Tropical Cyclone Recurvature, J. Appl. Meteor. Climatol., 52, 1394-1416, https://doi.org/10.1175/JAMC-D-12-045.1, 2013.

Zou, X. and Wu, Y.: On the relationship between Total Ozone Mapping Spectrometer (TOMS) ozone and hurricanes, J. Geophys. Res., 110, D06109, https://doi.org/10.1029/2004JD005019, 2005. 